\title{
Effects of professional baseball home fans' perceptions of community on their perceptions of stadium spaces
}

\author{
Wan-Young Lee ${ }^{1}$ \& Sun-Yong Kwon ${ }^{2 *}$ \\ ${ }^{1}$ Seoul National University Institute of Sport Science \& ${ }^{2}$ Seoul National University
}

\begin{abstract}
[Purpose] The purpose of this study is to examine effects of professional baseball home fans' perception of the community on their recognition of stadium spaces. [Methods] The subjects of the survey were home fans of baseball. A total of 600 questionnaire(100 fans each team: DOOSAN, LG, SK, LOTTE, HANHWA and KIA) were collected and 510 copies were used as the final analysis data. Collected data was processed by using SPSS 21.0 program. T-test, one-way ANOVA, correction analysis and multiple regression analysis were conducted to test hypothesis. [Results] There were significant differences of perceptions on community such as perceptions on sense of belonging; favored teams, perceptions on active involvement; gender and favored teams, perceptions on pride of the home town; gender, favored teams and glasses for viewing, and perceptions on classification; educational level and favored teams. There were significant differences of perceptions on stadium spaces such as perceptions on historicity; favored teams and viewing experience, perceptions on authenticity; favored teams and viewing experience, and perceptions on symbolism; age, favored teams and glasses for viewing. Among home fans' perceptions of their community, sense of belonging and pride of the home town had positive effects on their perceptions on historicity among perceptions of stadium spaces, while perceptions of classification had negative effects on them; sense of belonging and pride of the home town had positive effects on both perceptions of authenticity and symbolism. [Conclusions] The findings indicate that there is a close relationship between the community and professional baseball stadiums, and it is necessary to commonly enhance sense of belonging and pride of the home town for the community in order to promote positive perceptions on stadiums.
\end{abstract}

Key words: Professional baseball, Home fan, Community, Stadium spaces

\begin{abstract}
서 론
프로야구는 한국사회 관람스포츠 중 가장 인기 있는 종목 중 하나이다. 국내 프로스포츠 5 대 종목 중 프로야 구는 한해 840 만명의 관람객이 지역에 위치한 경기장 을 찾고 있으며, 그로 인한 경제파급효과가 약 2 조원에
\end{abstract}

논문 투고일 : 2019. 02. 28.

논문 수정일 : 2019. 04. 01.

게재 확정일 : 2019. 05. 14.

* 교신저자 : 권순용(kwonsy@snu.ac.kr).

* 이 논문은 2017 년 대한민국 교육부와 한국연구재단의 지원을 받

아 수행된 연구임(NRF-2017S1A5B5A01026420)
달하고 있다(Hwang, 2016). 이처럼 인기스포츠로서 위 상을 가진 프로야구는 1980년도 초 시민들을 우민화 하 고 동원된 근대화를 이룩하기 위한 전두환 정권의 $3 \mathrm{~S}$ 정 책의 일환으로 지역 기반의 기업 후원을 받아 시작되었 다(Cho, 2010; Hong, 2012). 시장논리가 아닌 정치적 목적을 품고 시작된 프로야구는 지방자치제가 실현된 시 점을 시작으로 지역사회의 정치·경제·사회문화적 상황 에 따라 프로야구에 대한 의미가 달라지는 경향이 있다 (Kim, 2011).

그중에서도 프로야구 경기가 열리는 야구장은 다양 한 담론들을 담고 있다. 야구장은 현재 공공시설물로써 
2018년 개정된 스포츠산업진흥법에 따라 프로구단에 최 장 25 년 장기임대를 주고 있다. 즉 현재 국내 10 개 야구 장의 주인은 지방자치단체이고 구단은 세입자(鿓入者)이 다(Kim, 2017). 이는 지역사회가 야구장을 운영하는 방 향성에 따라 야구장에 대한 의미가 달라질 수 있으며, 야 구장을 방문하는 관람 팬들의 지역사회와 프로야구에 대 한 인식에도 영향을 미칠 수 있음을 의미한다(Han, 2017; Lee, 2018; Park, 2012).

지역사회는 한 지역의 정치·경제·사회문화를 담아내고 있는 큰 울타리이며, 지리적·행정적 분할에 의해 또는 인 간관계에 의해 나누어진 사회이다(Sampson \& Groves, 1989). 지역사회 구성원인 시민들은 지역의 정치·경제·사 회문화적 요소에 따라 지역사회에 대한 인식이 달라진다. 즉, 지역사회 정치·경제 등과 같은 사회적 요소는 지역사 회 구성원들의 개인특성에 따른 가치관, 소득 옥구, 교육 열의 등에 영향을 미치며 서로 긴밀한 관계를 가지고 있 다(Kim, 2015). 지역사회 자원 중 하나인 프로야구 경기 장은 지역민들의 사회문화적 욕구를 충족시킬 수 있는 자 원이다. 경기장 내(inner)에서는 서로 다른 개인적·사회 적 배경을 가진 사람들이 모여 이질감을 느끼지만 같은 팀을 '응원'하며 동질감을 느끼는 등 경기장 외부에서는 겪기 힘든 독특한 경험을 할 수 있는 공간이기도 하다 (Chun et al., 2005).

이러한 거대 건축물인 야구경기장은 지역사회 속에서 다양한 의미를 가진다(Park \& Shin, 2014). 비록 건설 초기에는 많은 논란이 일어나지만 건설 이후에는 지역의 랜드마크(landmark)로써 자리매김 하여 지역사회와 궤 를 같이한다. 야구경기장은 건설이 완료된 직후에는 경기 를 실시하고 관람하는 목적을 주로 담당한다. 그러나 시 간이 지남에 따라 역사적, 경제적, 사회문화적 측면에서 가치있는 공간으로 변모하고 지역사회의 생활패턴, 예를 들어 근로시간 감축에 따른 여가시간 증가 등의 변화와 맞물려 지역 사회 내 여가 중심지로서 역할을 수행하게 된다(Kang et al., 2013). 더 나아가 지역연고를 기본으 로 하는 프로야구의 특성상 프로야구장은 지역시민들의 지역사회 자부심과 소속감 공동체 의식과 같은 지역사회 인식을 높이는 장(場)을 제공하기도 한다(Gratton \& Henry, 2002; Karp \& Yoels, 1990), 다시 말해서 지역 사회의 지역정체성을 발현할 수 있는 매개체로서 기능할 수 있는 까닭에 야구장은 도시 지역사회의 '상징적 구성 (symbolic construction)'에서 중요한 역할을 차지하며
(Cohen, 1985), 지역사회 단결의 구심점이 되고 공동사 회의 재구성을 위한 원천이 되고 있다(Bale, 1991).

프로야구장이 내포하고 있는 지역적 성격은 시민들의 지역사회에 대한 인식에 따라 야구경기장에 대한 인식을 다양하게 형성하기도 한다(Eckstein \& Delaney, 2002). 지역사회 자산인 경기장은 건설 이후 약 30 년 이상 지역 사회와 함께 한다는 점은 역사성과 상징성을 갖게 한다 (Cho, 2005; Ramshaw \& Gammon, 2010; Trujillo, 1992). 또한 역사성과 상징성 형성 과정 동안 지역사회에 서 일어나는 다양한 일련의 사건 혹은 일상들, 예컨대 정 치인들의 선전 도구로서 경기장 활용, 자치단체 장들의 표 몰이를 위한 공약 도구로서 활용, 지역 구단의 모기업과 지자체와의 갈등 등 지역사회와 경기장이 관계를 맺는 동안 형성되는 시민들의 지역사회 인식은 경기장 인식형 성에도 영향을 미치며 (Hwang \& Jung, 2012), 이는 지역 사회의 정책 기조와 분위기에 따라 경기장이 때로는 긍정 적 공간으로, 때로는 부정적 공간으로 자리매김 할 수 있 다. 또한, 각 지역 시민들의 성향이 다르듯 경기장 공간 내 팬들의 성향도 팀마다 차이가 있으며 지역구단 모기업의 특성과 지역의 특성이 다양한 형태로 경기장 공간 내에 반영되기 때문에 전국 프로야구장은 각기 다른 고유한 특 성도 가지고 있다(Kim \& Lee, 2015; Lamalfa, 2005).

지역사회와 경기장 공간과의 인식은 밀접한 관련성이 있음에도 불구하고 그동안 지역사회와 경기장 공간의 관 계에 대한 연구는 활발히 진행되지 않았다. 현재까지는 주 로 경기장 공간 인식에 관한 연구(Cho et al., 2012; Kim \& Jung, 2013), 지역사회 내 스포츠이벤트 이후 경기장 활용방안에 관한 연구(Lee, 2010; Moon, 2014; Yeom et al., 2018)와 지역사회 연계 및 관광자원으로의 활용을 위한 경기장 활용방안에 관한 연구(Jung \& Lee, 2017; Kang et al., 2013)가 진행되었다. 그러나 팬들의 지역사 회 인식이 지역사회 자산인 경기장 공간 인식에 미치는 영 향 또는 그들의 관계를 살핀 연구는 찾아보기 힘들다. 그 동안 우리는 지역사회 내에서 프로야구가 주는 경제적 이 익과 사회문화적 효과에 대해 주목해 온 반면 그러한 상 황이 펼쳐지는 경기장 공간에 대한 의미 연구는 소홀히 한 측면이 있다.

유료관중이 800만 명이 넘은 현재, 야구경기장에 대한 인식은 성인 팬들에게는 어린 시절 추억의 장소로, 연인 들에게는 데이트 장소로, 직장 동료 및 친구들에게는 친 목의 장소로, 아이를 둔 부모들에게는 테마파크로써 자리 
매김 하였다(Kim, 2017). 이처럼 프로야구 경기장은 지 역 팬들의 삶 속에 깊숙이 들어와 있으며 지역의 상징물 이자 역사로서 지역사회와 함께 호흡한다는 점을 고려해 볼 때 경기장 공간을 하나의 대상물로 보고 지역 팬들이 지역에 대해 가지고 있는 인식과 어떤 관련성을 가지고 있는지 연구해 보는 것은 가치가 있을 것으로 사료된다.

이에 본 연구는 국내 프로야구 6개 구단 홈 팬들의 개 인적 특성에 따른 지역사회 인식과 경기장 공간 인식을 우선적으로 살펴보고 지역사회 인식이 경기장 공간 인식 에 어떠한 영향을 미치는지 분석하고자 하며, 이를 통해 지역사회에서 프로야구경기장이 가지는 의미와 야구경 기장 공간의 긍정적 인식형성 강화를 위한 기초자료를 제 공하는 것을 연구의 목적으로 한다.

\section{연구문제}

이러한 목적을 달성하기 위해서 본 연구에서 설정한 연구문제는 다음과 같다.

1) 일반적 특성에 따른 지역사회와 야구경기장 공간 인식은 어떠한 차이가 있는가?

2) 지역사회 인식이 야구경기장 공간 인식에 미치는 영향은 어떠한가?

\section{연구방법}

\section{연구대상}

이 연구 대상은 서울, 인천, 대전, 광주, 부산에 위치 한 프로야구경기장을 방문한 두산, LG, SK, 한화, 기아, 롯데 구단 홈 팬들을 대상으로 조사를 실시하였다. 이 연 구의 주 목적인 홈 팬들의 지역사회 인식과 지역사회 내 에 위치한 야구경기장 공간 인식을 알아보기 위해 해당 거주지역을 고향으로 하고 있는 팬들을 대상으로 목적 표집법 (purposive sampling)을 사용해 연구 대상자를 선정하였다. 선정된 대상자에게는 설문지 배포 후 개인 의 생각과 느낌을 그대로 답변하게 하는 자기평가기입법 (self-administration)으로 조사를 실시하였다. 조사대 상 팀의 대전 형태와 대상자 규모는 다음과 같다. 서울 경 기는 'LG-롯데', '두산-한화'경기에서의 $\mathrm{LG}$ 팬과 두산팬
을 대상으로, 인천 경기는 'SK-기아'경기에서의 SK팬을 대상으로, 대전 경기는 '한화-두산'경기에서의 한화 팬을 대상으로, 광주 경기는 '기아-SK'경기에서의 기아 팬을 대상으로, 부산 경기는 '롯데-LG'경기에서의 롯데팬을 조 사 대상자로 선정하였다. 조사대상 규모는 경기당 홈 팬 100 명씩 6경기 총 600 명을 대상으로 600 부의 설문지를 배부하였으며, 이중 불성실한 응답, 조사내용 누락, 이중 기입으로 표기한 90 부를 제외한 총 510 부를 최종 분석 자료로 사용하였다.

Table 1. Characteristics subjects

\begin{tabular}{|c|c|c|c|}
\hline Variable & Category & $N$ & $\%$ \\
\hline \multirow{2}{*}{ Gender } & Male & 304 & 59.6 \\
\hline & Female & 206 & 40.4 \\
\hline \multirow{4}{*}{ Age } & $20-29$ & 201 & 39.4 \\
\hline & $30-39$ & 116 & 22.7 \\
\hline & $40-49$ & 133 & 26.1 \\
\hline & 50 and above & 60 & 11.8 \\
\hline \multirow{3}{*}{ Education } & High school or less & 100 & 19.6 \\
\hline & College & 103 & 20.2 \\
\hline & University & 307 & 60.2 \\
\hline \multirow{4}{*}{$\begin{array}{l}\text { Household } \\
\text { income } \\
\text { (W/KRW) }\end{array}$} & Below, 3,000,000 & 156 & 30.6 \\
\hline & $3,000,000-4,999,999$ & 151 & 29.6 \\
\hline & $5,000,000-6,999,999$ & 102 & 20.0 \\
\hline & $7,000,000$ and above & 101 & 19.8 \\
\hline \multirow{6}{*}{ Team } & Doosan & 89 & 17.4 \\
\hline & LG & 95 & 18.6 \\
\hline & SK & 74 & 14.5 \\
\hline & LOTTE & 71 & 13.9 \\
\hline & HANHWA & 96 & 18.8 \\
\hline & KIA & 85 & 16.6 \\
\hline \multirow{4}{*}{$\begin{array}{l}\text { Watching } \\
\text { experience }\end{array}$} & 2 years or less & 114 & 22.4 \\
\hline & $2-8$ years & 121 & 23.7 \\
\hline & $8-15$ years & 114 & 22.4 \\
\hline & More than 15 years & 161 & 31.6 \\
\hline
\end{tabular}

\section{조사도구}

홈팬 집단의 지역 사회인식이 지역사회 내 야구경기장 공간 인식에 미치는 영향을 분석하기 위해 사용된 조사도 구는 설문지이다. 설문지는 조사도구의 특성상 대상자들 
의 인식을 양적으로 측정하는 도구이기에 요인명을 함축 성 있게 설정하는 것이 중요하다. 따라서 본 연구는 우선 적으로 요인명의 구성과 해당 요인명의 함축적 의미를 기 술하고, 문항과 관련된 선행연구를 밝히고자 한다.

\section{일반적 특성}

본 연구는 지역 홈팬들의 지역사회 인식이 야구경기장 공간 인식에 미치는 영향을 분석하는 연구이다. 홈팬들의 지역사회 인식을 알아보기 위해서는 지역사회에서 어느 정도의 삶을 유지하고 있는지에 대한 기초 특성 조사가 선행되어야 하며, 야구경기장 공간 인식 조사를 위해서는 일정 기간 동안 야구경기장을 방문한 사람들의 방문 경력 을 통해 형성된 경기장의 인식을 알아보아야 한다. 따라 서 본 연구는 팬들의 지역사회 인식과 야구경기장 공간 인식을 살펴보기 위한 선행 변인으로 팬들의 성별, 나이, 교육, 가구소득, 응원팀, 관람경력을 일반적 특성으로 구 성하였다.

\section{지역사회 인식}

본 연구에서 말하고 있는 지역사회 인식에는 지역적 변인과 사회적 변인 및 문화·심리적 변인이 포함된다 (Hillery, 1995). 우선, 지역적 변인은 지역이라는 공동체 생활 속에 시민으로서 그 공동체 내에서의 공동 목표와 역할의식을 갖고 공동의 행동을 취하고자 하는 개념이다 (Yun \& Han, 2005). 이러한 개념에 근거하여 본 연구에 서는 사회 구성원으로서 취할 수 있는 지역사회 관여 인 식을 지역 변인 문항으로 설정하였다. 최종적으로 대상자 들의 지역 인식을 측정하기 위해 지역주민의 참여행동 연구(Yoo \& Park, 2006)에서 사용된 문항을 수정·보완 하여 지역 내 행사 참여, 지역 정책지지, 지역 발전을 위 한 의견제시, 거주 지역과의 지속적 관계 유지를 조사 문 항으로 설정하였다. 사회적 변인은 계층화 인식을 묻는 질 문이다. 사회적 변인에는 다양한 요소가 있으며 계층 인 식은 이를 구성하는 요소 중 하나이다. 계층의식은 다양 한 의미를 지닌다. 특히 사회 자원의 불평등한 분배 인지, 계층을 분리하는 요인 인지를 지칭하며, 자신이 속해 있 는 집단과의 일체감, 타 집단과의 비교 인식 등을 지칭하 기도 한다(Lopreato \& Hazelrigg, 1972). 따라서 본 연구 에서 사회적 변인은 앞선 계층의식에 대한 정의를 바탕으 로 도시에서의 소득수준에 따른 거주지 분리와 거주민의 사회통합 인식 연구(Yang, 2014)에서 사용된 계층화 인
식 문항을 활용하여 현재 거주지역에서 타인보다 더욱 나 은 경제적 삶과 교육, 높은 수준의 문화생활 향유, 더 큰 영향력을 가진 사람인지 여부를 묻는 문항으로 구성하여 계층화 인식을 알아보았다. 문화·심리적 변인은 조사대 상자들의 지역 사회에 대한 소속감과 자긍심을 의미한 다. 문화·심리적 변인은 지역사회에서 열리는 이벤트의 중요도나 규모, 지역사회가 가지고 있는 랜드마크 등에 따라 문화·심리적 변인의 차이가 달라진다(Son, 2014). 지역사회 소속감은 공동체를 이루는 구성원으로써 공동 체에 대한 개인이 인지하고 있는 귀속감정이라 할 수 있 으며 이러한 소속감은 사회화 과정의 기본적 요소이다 (Lee \& Robbins, 1995). 자긍심은 소속감과 상호관련성 있는 요소로써 지역사회의 여건에 따라 달라지는 개념이 다(Chae, 2016). 따라서 본 연구에서는 조사 대상자들의 소속감과 자긍심을 알아보기 위해 Kwon et al.(2010)과 $\operatorname{Kim}(2016)$ 이 사용한 문항 중 거주지역 주민인 것에 대 한 자랑스러움, 거주지역의 수준에 대한 긍정적 인식 등 을 자긍심 인식 측정문항으로 활용하였다. 소속감 문항 은 Hong et al.(2012)의 지역사회 소속감 문항을 본 연 구에 맞게 수정·보완하여 사용하였으며 타인의 거주지역 칭찬에 따른 인식, 자신의 거주지역에 대한 비난보도나 소문에 대한 인식 등을 소속감 인식 측정 문항으로 활용 하였다.

\section{경기장 공간 인식}

경기장 공간 인식은 지역사회 내에서 경기장 공간이 가지는 의미로써 경기장 공간이 어떤 역할을 수행해야 하 는가에 대한 질문이 아닌 어떤 의미를 가지는가에 관한 질문이다. 이를 위해 야구경기장 공간의미는 경기장이 가 지는 역사성, 고유성, 상징성에 관한 문항을 구성하였다. 우선 역사성은 경기장 공간이 가지는 유무형의 세월에 대 한 흔적과 과거에 대한 추억을 만들어가는 공간인지를 알 아보는 문항이다. 경기장 공간은 경기장이 이전하거나 리 모델링이 되기까지 많은 세월을 거치게 된다. 이에 따라 지역사회에서 경기장 공간이 가지는 다양한 의미 중 역사 적 의미에 대한 인식을 알아보고자 하였다. 이를 확인하 기 위해 Kim(1995)의 연구인 도시건축의 콘텍스트에 관 한 연구와 역사적 건축물의 재생을 통한 공공성 증진에 관한 연구에서 나타난 건축공간의 역사성에 관한 내용을 본 연구에 맞게 수정·보완하여 경기장 공간의 역사성과 추억, 세대 간의 공감대 형성에 관한 인식을 알아볼 수 있 
는 문항을 구성하였다. 고유성은 관광학에서 자주 등장하 는 요인으로 관찰자가 가지고 있는 관광대상에 대한 관 점, 신념, 전망, 그들의 지각, 삶의 경험에 의해 형성되는 인식이다(Cho \& Yang, 2004). 이에 본 연구에서의 고유 성은 해당 지역 팬들이 인식하는 경기장에 대한 관점이 며, 지역의 삶과 궤를 같이하고 있는 공간으로써 경기장 을 어떻게 인식하고 있는지 확인하는 문항이다. 이를 달 성하기 위해 $\mathrm{Cho}(2008)$ 의 연구에서 고유성 측정 문항을 본 연구에 맞게 수정·보완하여 사용하였으며, 경기장이 지역 고유의 특색과 분위기를 담아내고 있는 장소인지 를 측정하는 문항을 구성하였다. 경기장 공간에 대한 상 징성은 경기장 공간이 해당 도시를 대표할 수 있는 상징 적 의미를 지니고 있는가에 대한 질문이다. 현대사회에서 창의성과 전문성을 기반으로 한 상징적 건축물은 도시의 랜드마크가 되기 위한 요소 중 큰 부분을 차지하며 랜드 마크 건축물은 도시의 이미지를 대변할 수 있으며 도시 의 정체성과도 연결될 수 있다(Seo, 2017). 따라서 본 연 구에서는 도시에 있는 경기장 공간의 상징적 의미를 살 펴보고자 하며 Son(2014)의 연구에서 사용된 상징 건축 물에 대한 인식 문항을 본 연구에 맞게 수정·보완하여 사 용하였다. 본 연구에서 활용한 설문지는 일반적 특성 6 문 항, 지역사회 인식 15 문항(소속감: 3 문항, 적극관여 : 4 문 항, 자긍심 4 문항, 계층화 4 문항), 경기장 공간 인식 8 문 항(역사성 : 3 문항, 고유성 : 2 문항, 상징성 : 3 문항) 총 29 문항으로 구성하였다. 항목에 대한 척도는 기본적으로 명 목·서열 척도를 사용하였으며 1점: 전혀 아니다 부터 5 점: 매우 그렇다 까지 5점 리커트 척도로 구성하였다. 문 항의 명명과 문항 수, 구체적인 내용은 〈Table 2〉와 같다.

Table 2. Composition of the questionnaire

\begin{tabular}{lcc}
\hline \hline Factors & Contents & $N$ \\
\hline Characteristics & $\begin{array}{c}\text { Gender, Age, Academic background, } \\
\text { Household income, Team, } \\
\text { Watching experience }\end{array}$ & 6 \\
\hline \multirow{2}{*}{$\begin{array}{l}\text { Perception of } \\
\text { Community }\end{array}$} & Sense of Belonging & 3 \\
\cline { 2 - 3 } & Active Involvement & 4 \\
\cline { 2 - 3 } & Pride of the Home Town & 4 \\
\hline Perception of & Classification & 4 \\
\cline { 2 - 3 } Stadium Spaces & Historicity & 3 \\
\cline { 2 - 3 } & Authenticity & 2 \\
\hline \hline
\end{tabular}

\section{신뢰도 및 타당도 분석}

본 연구에서 사용한 측정도구의 타당도를 검증하기 위해 직교회전방식(Varimax)을 통한 요인분석 (Factor Analysis)을 실시하였으며, 요인의 Eigen value값이 1 이상인 요인만을 추출하였다. 신뢰도를 검증하기 위해 측 정항목에 대한 Chronbach's $\alpha$ 계수를 산출하였다. 지역 사회 인식은 소속감 .821, 적극관여 .876, 자긍심 .911, 계층화 .876으로 나타났으며〈Table 3〉, 경기장 공간 인 식은 역사성 .806 , 고유성 .914, 상징성 .883으로 나타나 〈Table 4〉 조사도구의 신뢰성을 확보하였다.

\section{자료수집 및 처리}

자료 수집 및 처리 과정은 우선, 수집된 각 자료를 부호 화(coding)하여 입력한 후 SPSS 21.0 프로그램을 이용 하여 연구의 목적에 따라 전산처리하였다. 구체적인 자료 분석방법은 다음과 같다. 홈 팬의 일반적 특성에 따른 지 역사회 인식, 경기장 공간 인식의 차이를 알아보기 위해 독립표본의 t-test와 일원변량분석 (one-way ANOVA)을 실시하였으며 사후검증은 Scheffe검증을 실시하였다. 그 리고 가설검증을 위하여 상관분석 (correlations analysis) 과 다중회귀분석 (multiple regression analysis)을 실시 하였으며 모든 통계치의 유의수준을 .05로 설정하였다.

\section{연구결과}

\section{조사대상의 일반적 특성에 따른 지역사회 인식, 경 기장 공간 인식의 차이}

\section{지역사회 인식}

〈Table 5〉에 의하면 지역사회 인식의 차이 중 소속감 인식은 응원팀에서 유의한 차이가 나타났다. 응원 팀에 따 른 인식은 기아 $(\mathrm{M}=4.02)$, 롯데 $(\mathrm{M}=3.77)$, 한화 $(\mathrm{M}=$ 3.63), $\mathrm{SK}(\mathrm{M}=3.60), \mathrm{LG}(\mathrm{M}=3.53)$, 두산 $(\mathrm{M}=3.12)$ 로 통계적으로 유의한 차이 ( $p<.001)$ 가 나타났으며 사후 검증을 실시한 결과 $\mathrm{LG}$, 롯데, 한화의 평균이 두산보다 높 게 나타났고 기아보다 낮게 나타났다. 적극관여 인식은 성 별, 응원팀에서 유의한 차이가 나타났다. 성별에 따른 인식 은 남성 $(\mathrm{M}=3.58)$, 여성 $(\mathrm{M}=3.43)$ 으로 나타났으며 통 
Table 3. Factor analysis on the awareness of local community

\begin{tabular}{|c|c|c|c|c|c|}
\hline & Question & $\begin{array}{c}\text { Sense of } \\
\text { Belonging }\end{array}$ & $\begin{array}{l}\text { Active } \\
\text { Involvement }\end{array}$ & $\begin{array}{l}\text { Pride of the } \\
\text { Home Town }\end{array}$ & $\begin{array}{l}\text { Classifi- } \\
\text { cation }\end{array}$ \\
\hline 1 & $\begin{array}{l}\text { I feel as if I was praised when people from other regions praise the region } \\
\text { where I live. }\end{array}$ & .719 & .159 & .407 & .172 \\
\hline 2 & I feel bad when I hear news or rumor that blame the region where I live. & .864 & .212 & .172 & .155 \\
\hline 3 & $\begin{array}{l}\text { I feel humiliated myself when people from other regions blame the region } \\
\text { where I live. }\end{array}$ & .716 & .399 & .078 & .177 \\
\hline 4 & If there is a chance, I will join local events held in the region where I live. & .221 & .709 & .203 & .235 \\
\hline 5 & I actively support various policies conducted in the region where I live. & .128 & .759 & .232 & .367 \\
\hline 6 & $\begin{array}{l}\text { I'm willing to propose my opinion for local development in the region } \\
\text { where I live if there is a chance. }\end{array}$ & .273 & .779 & .182 & .205 \\
\hline 7 & $\begin{array}{l}\text { I consider maintaining continuous relationships with the region where I live } \\
\text { as important. }\end{array}$ & .301 & .702 & .327 & .227 \\
\hline 8 & I'm proud of myself as a resident in the region where I live. & .347 & .153 & .777 & .221 \\
\hline 9 & I introduce the region where I live to other people with pride. & .282 & .254 & .799 & .187 \\
\hline 10 & I think that the region where I live has a high prestige. & .059 & .162 & .858 & .223 \\
\hline 11 & There are many things to present in the region where I live. & .090 & .288 & .813 & .188 \\
\hline 12 & I think I'm more influential than others in the region where I live. & .064 & .324 & .188 & .767 \\
\hline 13 & I think I'm more well-off than others in the region where I live. & .168 & .240 & .127 & .847 \\
\hline 14 & I think I'm better educated than others in the region where I live. & .177 & .190 & .235 & .824 \\
\hline 15 & I think I enjoy high-level cultural life than others in the region where I live. & .165 & .183 & .264 & .762 \\
\hline & Initial Eigenvalues & 2.309 & 2.912 & 2.959 & 3.352 \\
\hline & Variance & 21.679 & 19.725 & 19.412 & 15.391 \\
\hline & Cumulative Variance & 21.679 & 41.404 & 60.816 & 76.207 \\
\hline & Chronbach's $\alpha$ & .821 & .876 & .911 & .876 \\
\hline \multicolumn{6}{|c|}{$\mathrm{KMO}=.910$, Barteltt's $x^{2}=5274.737(p<.001)$} \\
\hline
\end{tabular}

Table 4. Factor analysis on the awareness of sporting spaces

\begin{tabular}{|c|c|c|c|c|}
\hline & Question & Historicity & Authenticity & Symbolism \\
\hline 1 & This stadium is a place where local historicity is created. & 609 & .397 & .293 \\
\hline 2 & This stadium is a place where you can make a variety of memories. & .912 & .060 & .204 \\
\hline 3 & This stadium is a place where consensus across generations is created. & .761 & .313 & .240 \\
\hline 4 & This stadium is a place where unique local ambience is evoked. & .242 & .819 & .372 \\
\hline 5 & This stadium is an attractive place where local features are harmonized with history. & .232 & .831 & .388 \\
\hline 6 & This stadium has a symbol representing the region. & .256 & .256 & .849 \\
\hline 7 & This stadium is a landmark creating local images. & .186 & .363 & .845 \\
\hline 8 & This stadium has value of urban landmark. & .299 & .374 & .702 \\
\hline & Initial Eigenvalues & 2.059 & 2.073 & 2.414 \\
\hline & Variance & 30.175 & 25.917 & 25.737 \\
\hline & Cumulative Variance & 30.175 & 56.091 & 81.828 \\
\hline & Chronbach's $\alpha$ & .806 & .914 & .883 \\
\hline & \multicolumn{4}{|l|}{$\mathrm{KMO}=.872$, Barteltt's $x^{2}=2814.850(p<.001)$} \\
\hline
\end{tabular}


Table 5. The difference between the awareness of local community and the awareness of sporting spaces in accordance with the general characteristics

\begin{tabular}{|c|c|c|c|c|c|c|c|c|c|}
\hline \multirow{2}{*}{ Characteristic } & & \multirow{2}{*}{$N$} & \multicolumn{4}{|c|}{ Perception of Community } & \multicolumn{3}{|c|}{ Perception of Stadium Spaces } \\
\hline & & & $\begin{array}{c}\text { Sense of } \\
\text { Belonging }\end{array}$ & $\begin{array}{c}\text { Active } \\
\text { Involvement }\end{array}$ & $\begin{array}{l}\text { Pride of the } \\
\text { Home Town }\end{array}$ & $\begin{array}{l}\text { Classifi- } \\
\text { cation }\end{array}$ & Historicity & Authenticity & Symbolism \\
\hline \multirow{3}{*}{ Gender } & Male & 304 & $3.56 \pm .792$ & $3.58 \pm .734$ & $3.56 \pm .795$ & $3.26 \pm .798$ & $3.91 \pm .705$ & $3.65 \pm .887$ & $3.72 \pm .876$ \\
\hline & Female & 206 & $3.66 \pm .769$ & $3.43 \pm .776$ & $3.41 \pm .713$ & $3.18 \pm .741$ & $3.94 \pm .643$ & $3.48 \pm .890$ & $3.75 \pm .800$ \\
\hline & $t$ & & -1.398 & $2.180^{*}$ & $2.147^{*}$ & 1.183 & -.523 & 2.090 & -.283 \\
\hline \multirow{6}{*}{ Age } & $20-29$ & (a)201 & $3.57 \pm .840$ & $3.53 \pm .807$ & $3.67 \pm .868$ & $3.30 \pm .847$ & $4.01 \pm .680$ & $3.68 \pm .958$ & $3.82 \pm .829$ \\
\hline & 30-39 & (b) 116 & $3.60 \pm .700$ & $3.43 \pm .709$ & $3.41 \pm .641$ & $3.15 \pm .737$ & $3.89 \pm .730$ & $3.66 \pm .889$ & $3.81 \pm .854$ \\
\hline & $40-49$ & (c) 133 & $3.62 \pm .778$ & $3.50 \pm .717$ & $3.38 \pm .699$ & $3.18 \pm .717$ & $3.83 \pm .672$ & $3.40 \pm .900$ & $3.61 \pm .809$ \\
\hline & 50 and above & (d) 60 & $3.67 \pm .767$ & $3.73 \pm .709$ & $3.38 \pm .671$ & $3.26 \pm .716$ & $3.87 \pm .572$ & $3.53 \pm .965$ & $3.54 \pm .916$ \\
\hline & $F$ & & .272 & 2.144 & 5.459 & 1.212 & 2.184 & $3.003^{*}$ & $3.153^{*}$ \\
\hline & Scheffe & & & & & & & & \\
\hline \multirow{5}{*}{ Education } & High school or less & (a) 100 & $3.61 \pm .938$ & $3.50 \pm .810$ & $3.47 \pm .887$ & $3.10 \pm .785$ & $3.93 \pm .760$ & $3.59 \pm .920$ & $3.80 \pm .824$ \\
\hline & College & (b) 103 & $3.48 \pm .832$ & $3.47 \pm .751$ & $3.42 \pm .710$ & $3.10 \pm .799$ & $3.81 \pm .718$ & $3.43 \pm .954$ & $3.59 \pm .930$ \\
\hline & University & (c) 307 & $3.64 \pm .707$ & $3.55 \pm .737$ & $3.54 \pm .741$ & $3.32 \pm .755$ & $3.95 \pm .638$ & $363 \pm .929$ & $3.76 \pm .820$ \\
\hline & $F$ & & 1.056 & 6.853 & .450 & $1.630^{*}$ & 1.579 & 1.805 & 1.858 \\
\hline & Scheffe & & & & & $\mathrm{a}, \mathrm{b}<\mathrm{c}$ & & & \\
\hline \multirow{6}{*}{$\begin{array}{l}\text { Household } \\
\text { income } \\
\text { (W/KRW) }\end{array}$} & Below, 3,000,000 & (a) 156 & $3.70 \pm .733$ & $3.49 \pm .769$ & $3.51 \pm .778$ & $3.22 \pm .796$ & $3.94 \pm .709$ & $3.64 \pm .854$ & $3.86 \pm .740$ \\
\hline & $3,000,000-4,999,999$ & (b) 151 & $3.56 \pm .739$ & $3.54 \pm .668$ & $3.42 \pm .639$ & $3.14 \pm .712$ & $3.92 \pm .634$ & $3.59 \pm .855$ & $3.64 \pm .807$ \\
\hline & $5,000,000-6,999,999$ & (c) 102 & $3.55 \pm .898$ & $3.66 \pm .818$ & $3.52 \pm .800$ & $3.28 \pm .805$ & $3.96 \pm .647$ & $3.56 \pm .976$ & $3.68 \pm .912$ \\
\hline & $6,000,000$ and above & (d) 101 & $3.56 \pm .800$ & $3.39 \pm .768$ & $3.59 \pm .876$ & $3.34 \pm .800$ & $3.85 \pm .738$ & $3.49 \pm 1.112$ & $3.73 \pm .966$ \\
\hline & $F$ & & 1.161 & 2.334 & 1.068 & 1.524 & .484 & .567 & 1.836 \\
\hline & Scheffe & & & & & & & & \\
\hline \multirow{8}{*}{ Team } & Doosan & (a) 89 & $3.12 \pm .906$ & $3.24 \pm .812$ & $3.19 \pm .777$ & $3.01 \pm .852$ & $3.87 \pm .661$ & $3.20 \pm 1.104$ & $3.51 \pm .858$ \\
\hline & LG & (b)95 & $3.53 \pm .807$ & $3.49 \pm .852$ & $3.50 \pm .735$ & $3.22 \pm .734$ & $3.88 \pm .697$ & $3.57 \pm .931$ & $3.66 \pm .903$ \\
\hline & SK & (c) 74 & $3.60 \pm .750$ & $3.56 \pm .755$ & $3.37 \pm .746$ & $3.16 \pm .692$ & $4.03 \pm .654$ & $3.60 \pm .794$ & $3.72 \pm .793$ \\
\hline & LOTTE & (d) 71 & $3.77 \pm .606$ & $3.75 \pm .747$ & $3.75 \pm .720$ & $3.41 \pm .908$ & $4.05 \pm .632$ & $3.93 \pm .801$ & $3.94 \pm .794$ \\
\hline & HANHWA & (e) 96 & $3.63 \pm .759$ & $3.49 \pm .681$ & $3.46 \pm .765$ & $3.27 \pm .739$ & $3.72 \pm .704$ & $3.51 \pm .951$ & $3.63 \pm .900$ \\
\hline & KIA & (f) 85 & $4.02 \pm .476$ & $3.67 \pm .550$ & $3.77 \pm .699$ & $3.35 \pm .678$ & $4.03 \pm .673$ & $3.77 \pm .796$ & $4.00 \pm .694$ \\
\hline & $F$ & & $14.242^{* * *}$ & $4.620^{* * *}$ & $7.587^{* * *}$ & $2.887^{*}$ & $3.153^{* *}$ & $6.091^{* * *}$ & $4.274^{* * *}$ \\
\hline & Scheffe & & $\mathrm{a}<\mathrm{b}, \mathrm{d}, \mathrm{e},<\mathrm{f}$ & $\mathrm{a}<\mathrm{d}, \mathrm{f}$ & $\mathrm{a}<\mathrm{d}, \mathrm{f} / \mathrm{a}, \mathrm{c}<\mathrm{f}$ & & & $\mathrm{a}<\mathrm{d}, \mathrm{f}$ & $a<f$ \\
\hline \multirow{6}{*}{$\begin{array}{l}\text { Watching } \\
\text { experience }\end{array}$} & 2 years or less & (a)114 & $3.51 \pm .880$ & $3.38 \pm .726$ & $3.43 \pm .819$ & $3.21 \pm .776$ & $3.82 \pm .681$ & $3.59 \pm .949$ & $3.73 \pm .828$ \\
\hline & $2-8$ years & (b) 121 & $3.53 \pm .799$ & $3.45 \pm .762$ & $3.44 \pm .818$ & $3.27 \pm .836$ & $3.83 \pm .700$ & $3.43 \pm .950$ & $3.71 \pm .834$ \\
\hline & $8-15$ years & (c)114 & $3.71 \pm .745$ & $3.68 \pm .771$ & $3.68 \pm .684$ & $3.28 \pm .706$ & $4.03 \pm .637$ & $3.73 \pm .852$ & $3.91 \pm .836$ \\
\hline & More than 15 years & (d) 161 & $3.64 \pm .719$ & $3.57 \pm .735$ & $3.47 \pm .727$ & $3.19 \pm .780$ & $3.98 \pm .682$ & $3.58 \pm .957$ & $3.63 \pm .860$ \\
\hline & $F$ & & 1.700 & 3.834 & $2.803^{*}$ & .449 & $2.861^{*}$ & 2.077 & $2.634^{*}$ \\
\hline & Scheffe & & & & & & & & \\
\hline
\end{tabular}

$\bar{c} p<.05,{ }^{* *} p<.01,{ }^{* * *} p<.001$ 
계적으로 유의한 차이 $(p<.05)$ 가 나타났다. 응원팀에 따른 인식은 롯데 $(\mathrm{M}=3.75)$, 기아 $(\mathrm{M}=3.67), \mathrm{SK}(\mathrm{M}=3.56)$, $\mathrm{LG}(\mathrm{M}=3.49)$, 한화 $(\mathrm{M}=3.49)$, 두산 $(\mathrm{M}=3.24)$ 로 통계 적으로 유의한 차이 $(p<.001)$ 가 나타났으며 사후검증을 실시한 결과 두산보다 롯데와 기아의 평균이 높게 나타났 다. 자긍심 인식은 성별, 응원팀, 관람경력에서 유의한 차 이가 나타났다. 성별에 따른 인식은 남성 $(\mathrm{M}=3.56)$, 여성 $(\mathrm{M}=3.41)$ 로 나타났으며 통계적으로 유의한 차이 $(p$ < $.05)$ 가 나타났다. 응원팀에 따른 인식은 기아 $(\mathrm{M}=3.77)$, 롯데 $(\mathrm{M}=3.75), \mathrm{LG}(\mathrm{M}=3.50)$, 한화 $(\mathrm{M}=3.46), \mathrm{SK}$ $(\mathrm{M}=3.37)$, 두산 $(\mathrm{M}=3.19)$ 로 통계적으로 유의한 차이 ( $p$ <.001)가 나타났으며 사후검증을 실시한 결과 두산보 다 롯데와 기아의 평균이 높게 나타났고 두산과 SK보다 기아의 평균이 높게 나타났다. 관람경력에 따른 인식은 815 년( $\mathrm{M}=3.68), 15$ 년 이상( $\mathrm{M}=3.47), 2-8$ 년( $\mathrm{M}=3.44)$, 2 년 미만 $(\mathrm{M}=3.43)$ 으로 통계적으로 유의한 차이 $(p<.05)$ 가 나타났으나 사후검증에서는 유의한 차이가 나타나지 않았다. 계층화 인식은 학력, 응원팀에서 유의한 차이가 나타났다. 학력에 따른 인식은 대졸 $(\mathrm{M}=3.32)$, 전문대졸 $(\mathrm{M}=3.10)$, 고졸 $(\mathrm{M}=3.10)$ 로 통계적으로 유의한 차이 ( $p<.05)$ 가 나타났으며 사후검증을 실시한 결과 고졸, 전 문대졸보다 대졸의 평균이 높게 나타났다. 응원팀에 따른 인식은 롯데 $(\mathrm{M}=3.41)$, 기아 $(\mathrm{M}=3.35)$, 한화 $(\mathrm{M}=3.27)$, $\mathrm{LG}(\mathrm{M}=3.22), \mathrm{SK}(\mathrm{M}=3.16)$, 두산 $(\mathrm{M}=3.01)$ 로 통계 적으로 유의한 차이 $(p<.05)$ 가 나타났으나 사후검증에서 는 유의한 차이가 나타나지 않았다.

\section{경기장 공간 인식}

〈Table 5〉에 의하면 경기장 공간 인식 차이 중 역사성 인식은 응원팀과 관렴경력에서 유의한 차이가 나타났다. 응원팀에 따른 인식은 롯데 $(\mathrm{M}=4.05), \mathrm{SK}(\mathrm{M}=4.03)$, 기아 $(\mathrm{M}=4.03), \mathrm{LG}(\mathrm{M}=3.88)$, 두산 $(\mathrm{M}=3.87)$, 한화 $(\mathrm{M}=3.72)$ 로 통계적으로 유의한 차이 $(p<.01)$ 가 나타났 으나 사후검증에서는 유의한 차이가 나타나지 않았다. 관 람경력에 따른 인식은 8-15년 $(\mathrm{M}=4.03), 15$ 년 이상 $(\mathrm{M}=$ 3.98), 2-8년 $(\mathrm{M}=3.83), 2$ 년 미만 $(\mathrm{M}=3.82)$ 로 통계적 으로 유의한 차이 $(p<.05)$ 가 나타났으나 사후검증에서 는 유의한 차이가 나타나지 않았다. 고유성 인식은 나이, 응원팀에서 유의한 차이가 나타났다. 나이에 따른 인식은 20 대 미만 $(\mathrm{M}=3.68), 30$ 대 $(\mathrm{M}=3.66), 50$ 대 이상 $(\mathrm{M}=$ $3.53), 40$ 대 $(\mathrm{M}=3.40)$ 으로 통계적으로 유의한 차이 $(p$ <
.05)가 나타났으나 사후검증에서는 유의한 차이가 나타 나지 않았다. 응원팀에 따른 인식은 롯데 $(\mathrm{M}=3.93)$, KIA $(\mathrm{M}=3.77), \mathrm{SK}(\mathrm{M}=3.60), \mathrm{LG}(\mathrm{M}=3.57)$, 한화 $(\mathrm{M}=$ $3.51)$, 두산 $(\mathrm{M}=3.20)$ 으로 통계적으로 유의한 차이 $(p<$ .001)가 나타났으며 사후검증을 실시한 결과 두산보다 롯데와 기아의 평균이 높게 나타났다.

상징성 인식은 나이, 응원팀, 관람경력에서 유의한 차 이가 나타났다. 나이에 따른 인식은 20 대 미만 $(\mathrm{M}=3.82)$, 30 대 $(\mathrm{M}=3.81), 40$ 대 $(\mathrm{M}=3.61), 50$ 대 이상 $(\mathrm{M}=3.54)$ 로 통계적으로 유의한 차이 $(p<.05)$ 가 나타났으나 사후 검증에서는 유의한 차이가 나타나지 않았다. 응원 팀에 따른 인식은 기아 $(\mathrm{M}=4.00)$, 롯데 $(\mathrm{M}=3.94), \mathrm{SK}(\mathrm{M}=$ 3.72), $\mathrm{LG}(\mathrm{M}=3.66)$, 한화 $(\mathrm{M}=3.63)$, 두산 $(\mathrm{M}=3.51)$ 로 통계적으로 유의한 차이 $(p<.001)$ 가 나타났으며 사후 검증을 실시한 결과 두산보다 기아의 평균이 높게 나타났 다. 관람경력에 따른 인식은 8-15년 $(\mathrm{M}=3.91), 2$ 년 미만 $(\mathrm{M}=3.73), 2-8$ 년 $(\mathrm{M}=3.71), 15$ 년 이상 $(\mathrm{M}=3.63)$ 로 통계적으로 유의한 차이 $(p<.05)$ 가 나타났으나 사후검 증에서는 유의한 차이가 나타나지 않았다.

\section{조사대상의 지역사회 인식과 경기장 공간 인식 간 의 관계}

본 연구를 통해 검정하고자 하는 변수들간의 관련성 정도와 방향을 파악하기 위하여 상관관계분석을 실시하 였다. 〈Table 6>과 같이 조사대상인 홈 팬들의 지역사회 대한 인식과 야구경기장 공간에 대한 인식 간의 관계를 분석하기 위하여 Pearson의 적률상관계수를 산출하여 분석하였으며 요인간의 상관관계는 $p<.01$ 수준에서 정 적인 상관관계를 보여주었다.

\section{조사대상의 지역사회 인식이 경기장 공간 인식 중 r역사성 인식,에 미치는 영향}

〈Table 7〉의 결과를 보면 $\mathrm{R}^{2}$ 는 .232로 지역사회인식 이 경기장 공간 인식 중 역사성 요인의 $23.2 \%$ 를 설명하 며 F값은 38.177로 회귀식이 통계적으로 유의한 것으로 나타났다 $(p<.001)$. 홈 팬의 지역사회인식 중「소속감」 인식의 회귀계수는 .203이며 t값은 4.495로 통계적으로 유의한 영향 $(p<.001)$ 을 미치는 것으로 나타났다. 「지역 자긍」인식의 회귀계수는 .296이며 t값은 6.477로 통계 적으로 유의한 영향 $(p<.001)$ 을 미치는 것으로 나타났으 
Table 6. The relationship between the awareness of local community and the awareness of sporting spaces

\begin{tabular}{|c|c|c|c|c|c|c|c|c|c|}
\hline & & & 1 & 2 & 3 & 4 & 5 & 6 & 7 \\
\hline \multirow{4}{*}{$\begin{array}{l}\text { Perception of } \\
\text { Community }\end{array}$} & 1 & Sense of Belonging & 1 & & & & & & \\
\hline & 2 & Active Involvement & $.621^{* *}$ & 1 & & & & & \\
\hline & 3 & Pride of the Home Town & $.542^{* *}$ & $.583^{* *}$ & 1 & & & & \\
\hline & 4 & Classification & $.480^{* *}$ & $.645^{* *}$ & $.535^{* *}$ & 1 & & & \\
\hline \multirow{3}{*}{$\begin{array}{l}\text { Perception of } \\
\text { Stadium Spaces }\end{array}$} & 5 & Historicity & $.389^{* *}$ & $.322^{* *}$ & $.421^{* *}$ & $.172^{* *}$ & 1 & & \\
\hline & 6 & Authenticity & $.485^{* *}$ & $.435^{* *}$ & $.473^{* *}$ & $.367^{* *}$ & $.613^{* *}$ & 1 & \\
\hline & 7 & Symbolism & $.473^{* *}$ & $.412^{* *}$ & $.529^{* *}$ & $.359^{* *}$ & $.616^{* *}$ & $.747^{* *}$ & 1 \\
\hline
\end{tabular}

Table 7. Effects of awareness of local society on awareness of stadium spaces historicity

\begin{tabular}{|c|c|c|c|c|c|c|c|}
\hline & Factor & $\mathrm{B}$ & SE & $\beta$ & $\mathrm{t}$ & Tolerance & VIF \\
\hline & Constant & 2.355 & .148 & & 15.872 & & \\
\hline \multirow{5}{*}{$\begin{array}{l}\text { Perception of } \\
\text { Community }\end{array}$} & Sense of Belonging & .203 & .045 & .234 & $4.495^{* * *}$ & .563 & 1.776 \\
\hline & Active Involvement & .092 & .053 & .102 & 1.726 & .434 & 2.305 \\
\hline & Pride of the Home Town & .296 & .046 & .333 & $6.477^{* * *}$ & .575 & 1.739 \\
\hline & Classification & -.162 & .046 & -.185 & $-3.488^{* * *}$ & .543 & 1.840 \\
\hline & Dependent Variable $=$ Historicity & \multicolumn{2}{|c|}{$\mathrm{R}^{2}=.232 \mathrm{~F}=38.177^{* * * *}$} & \multicolumn{3}{|c|}{ Durbin-Watson $=1.878$} & \\
\hline
\end{tabular}

며「계층화」 인식의 회귀계수는 - .162 이며 t값은 -3.488 로 통계적으로 유의한 영향( $p<.001)$ 을 미치는 것으로 나 타났다. 다중회귀분석을 위한 과정 중 하나로 다중공선성 을 확인해 본 결과 VIF는 모두 10이하였으며, 공차한계 는 0.1 보다 크기 때문에 다중공선성은 없는 것으로 나타 났다. 또한, Durbin-Watson은 1.878 로 기준값인 2에 매우 근접하고 0 또는 4 에 가깝지 않기 때문에 잔차들 간 에 상관관계가 없는 것으로 판단되며 이는 회귀모형이 적 합하다고 해석할 수 있다. 〈Table 7〉의 결과에서 보면 홈 팬들의 지역사회 인식 중 소속감 인식과 지역자긍심은 높 을수록, 계층화 인식은 낮을수록 경기장 공간의 역사성 인식이 높게 나타난다는 것을 알 수 있다.

\section{조사대상의 지역사회 인식이 경기장 공간 인식 중 「고유성 인식,에 미치는 영향}

〈Table 8〉의 결과를 보면 $\mathrm{R}^{2}$ 는 .306으로 지역사회 인
식이 경기장 공간 인식 중 고유성 요인의 $30.6 \%$ 를 설명 하며 F값은 55.638로 회귀식이 통계적으로 유의한 것 으로 나타났다 $(p<.001)$. 홈 팬의 지역사회 인식 중 「소속 감」 인식의 회귀계수는 .323이며 t 값은 5.488 로 통계적 으로 유의한 영향 $(p<.001)$ 을 미치는 것으로 나타났다. 「지역자긍」 인식의 회귀계수는 .303이며 t값은 5.081로 통계적으로 유의한 영향 ( $p$ 〈.001)을 미치는 것으로 나타 났다. 다중회귀분석을 위한 과정 중 하나로 다중공선성을 확인해 본 결과 VIF는 모두 10이하였으며, 공차한계는 0.1 보다 크기 때문에 다중공선성은 없는 것으로 나타났 다. 또한, Durbin-Watson은 1.960으로 기준값인 2에 매 우 근접하고 0 또는 4 에 가깝지 않기 때문에 잔차들 간에 상관관계가 없는 것으로 판단되며 이는 회귀모형이 적합 하다고 해석할 수 있다. 〈Table 8>의 결과에서 보면 홈 팬 들의 지역사회 인식 중 소속감 인식과 지역자긍심은 높을 수록 야구경기장 공간의 고유성 인식이 높게 나타난다는 것을 알 수 있다. 
Table 8. Effects of awareness of local society on awareness of stadium spaces authenticity

\begin{tabular}{|c|c|c|c|c|c|c|c|}
\hline & Factor & $\mathrm{B}$ & SE & $\beta$ & $\mathrm{t}$ & Tolerance & VIF \\
\hline & Constant & .781 & .194 & & 4.033 & & \\
\hline \multirow{5}{*}{$\begin{array}{l}\text { Perception of } \\
\text { Community }\end{array}$} & Sense of Belonging & .323 & .059 & .271 & $5.488^{* * *}$ & .563 & 1.776 \\
\hline & Active Involvement & .117 & .070 & .095 & 1.681 & .434 & 2.305 \\
\hline & Pride of the Home Town & .303 & .060 & .248 & $5.081^{* * *}$ & .575 & 1.739 \\
\hline & Classification & .051 & .061 & .043 & .845 & .543 & 1.840 \\
\hline & Dependent Variable $=$ Authenticity & \multicolumn{3}{|c|}{$\mathrm{R}^{2}=.306 \mathrm{~F}=55.638^{* * *}$} & \multicolumn{2}{|c|}{ Durbin-Watson $=1.960$} & \\
\hline
\end{tabular}

Table 9. Effects of awareness of local society on awareness of stadium spaces symbolism

\begin{tabular}{|c|c|c|c|c|c|c|c|}
\hline & Factor & $\mathrm{B}$ & SE & $\beta$ & $\mathrm{t}$ & Tolerance & VIF \\
\hline & Constant & 1.166 & .172 & & 6.770 & & \\
\hline \multirow{5}{*}{$\begin{array}{l}\text { Perception of } \\
\text { Community }\end{array}$} & Sense of Belonging & .263 & .052 & .244 & $5.020^{* * *}$ & .563 & 1.776 \\
\hline & Active Involvement & .034 & .062 & .030 & .547 & .434 & 2.305 \\
\hline & Pride of the Home Town & .402 & .053 & .364 & $7.578^{* * *}$ & .575 & 1.739 \\
\hline & Classification & .030 & .054 & .028 & .566 & .543 & 1.840 \\
\hline & Dependent Variable $=$ Symbolism & \multicolumn{2}{|c|}{$\mathrm{R}^{2}=.330 \mathrm{~F}=60.250^{* * *}$} & \multicolumn{3}{|c|}{ Durbin-Watson $=2.092$} & \\
\hline
\end{tabular}

\section{조사대상의 지역사회 인식이 경기장 공간 인식 중 r상징성 인식,에 미치는 영향}

〈Table 9〉의 결과를 보면 $\mathrm{R}^{2}$ 는 .330으로 지역사회 인 식이 경기장 공간 인식 중 상징성 요인의 $33 \%$ 를 설명 하며 F값은 62.250 으로 회귀식이 통계적으로 유의한 것 으로 나타났다 $(p<.001)$. 홈 팬의 지역사회 인식 중「소 속감」 인식의 회귀계수는 .263이며 t값은 5.020으로 통 계적으로 유의한 영향 $(p<.001)$ 을 미치는 것으로 나타 났으며「지역자긍」인식의 회귀계수는 .402이며 t값은 7.578 로 통계적으로 유의한 영향 $(p<.001)$ 을 미치는 것 으로 나타났다. 다중회귀분석을 위한 과정 중 하나로 다 중공선성을 확인해 본 결과 VIF는 모두 10 이하였으며, 공차한계는 0.1 보다 크기 때문에 다중공선성은 없는 것 으로 나타났다. 또한, Durbin-Watson은 2.092로 기준값 인 2 에 매우 근접하고 0 또는 4 에 가깝지 않기 때문에 잔 차들 간에 상관관계가 없는 것으로 판단되며 이는 회귀모 형이 적합하다고 해석할 수 있다. 〈Table 9〉의 결과에서 보면 홈 팬들의 지역사회 인식 중 소속감 인식과 지역자
긍심은 높을수록 야구경기장 공간의 상징성 인식이 높게 나타난다는 것을 알 수 있다.

\section{논 의}

이 연구는 프로야구 홈 팬들이 가지고 있는 지역사회 인식과 프로야구 경기장 공간 인식 간의 관계를 살펴보기 위해 실시 된 연구이다. 본 연구결과와 선행연구를 바탕 으로 다음과 같은 논의를 실시하고자 한다.

\section{일반적 특성에 따른 지역사회 인식 중 소속감 요인 논의}

응원팀에 따른 지역사회 소속감 인식에서는 기아 팀 이 속해있는 광주지역 팬들의 지역사회 소속감이 가장 큰 것으로 나타났다. 일반적으로 지역사회 소속감은 지역 공동체 의식 형성 전 단계로써 많은 도시들은 도시 이벤 트를 지역사회 소속감 향상을 위한 도구로써 사용하는 경 
향이 존재한다(Hwang \& Jung, 2012). 즉 지역사회 주민 들이 추진 주체로서든, 아니면 소극적 참여자(예컨대, 관 객)로든 도시 이벤트에 참여하는 경험을 통해 지역사회 에 대한 소속감이 함양되고 증진되는 것이다. 이러한 측 면에서 광주광역시는 과거 1980 년대 $5 \cdot 18$ 민주항쟁을 기 리는 광주 $5 \cdot 18$ 기념행사와 기아타이거즈의 활약은 지역 사회 소속감 향상에 핵심적 역할을 하는 것으로 사료된다. 일반적으로 도시 축제들을 활용한 지역소속감의 관계를 연구한 많은 연구들은 기념의례나 문화예술행사 또는 지 역연고제와 관련 있는 프로스포츠를 주요주제로 다루고 있는 경우가 많다(Park \& Chang, 2009). 이러한 측면에 서 광주광역시는 매력적인 두 가지 자원을 가지고 있다고 볼 수 있다. 첫째, 광주 $5 \cdot 18$ 기념행사는 1980 년 5 월 광 주 민주화운동을 기념하는 일련의 행사들로 구성되며 그 규모가 점차 확대되고 있다는 것이다. 매년 5 월을 전후로 약 한 달 동안 광주시내 각지에서는 각종 기념 및 추모행 사가 열리며 많은 시민·사회단체 관계자들이 자원봉사에 참여하는 등 다른 지역에서는 쉽게 모방하기 힘든 광주만 의 독특한 문화행사를 진행함으로써 지역 시민들의 지역 사회 소속감을 높이고 있다. 프로야구단 운영도 마찬가지 이다. 프로야구는 지역연고제를 기반으로 하기 때문에 지 역사회 소속감을 높이기에 효율적인 도구가 된다(Gratton $\&$ Henry, 2002). 둘째, 기아타이거즈는 과거 해태타이거즈 시절 영·호남 대결구도의 주인공이었다는 점이다. 또한, 1980년대 민주항쟁시절 해태타이거즈는 광주시민들의 울 분을 달래주는 기제로써 지역시민들의 응집력 항상에 중요 한 영향을 미쳤다. 이처럼 광주지역은 다양한 도시 이벤트 (의례, 프로스포츠팀 등)를 보유함으로써 지역시민들의 지 역사회 소속감을 향상시키고 있는 것으로 생각된다. 따라 서 본 연구 대상 중 하나인 광주기아 팬 집단도 지역사회 에서 열리는 다양한 의례와 프로야구팀의 영향을 받고 있 는 것으로 보이며 이러한 자원들은 지역사회 소속감 향상 에 긍정적 영향을 미치고 있는 것으로 해석해 볼 수 있다.

\section{일반적 특성에 따른 지역사회 인식 중 적극관여 요 인 논의}

성별에 따른 인식에서는 남성 집단의 적극관여 인식이 가장 높게 나타났다. 결과에서 확인할 수 있듯 남성 $(\mathrm{M}=$ $3.58)$ 이 여성 $(\mathrm{M}=3.43)$ 에 비해 지역사회 적극관여 인 식이 근소하게 앞서있다. 최근 남녀가 지역사회에 관여 하는 비율은 선거 이외에 모든 부분에서 낮아지고 있는
추세이다. 그럼에도 불구하고 아직까지 공공기관 및 기 업 내 의사결정자는 남성인 경우가 많으며 사회문화 부분 에서도 남성이 주도권을 가지고 있는 상황이다(Chea, 2003; Jung, 2017). 환언해보면 정책 및 의사결정의 주 도권을 쥐고 있는 남성이 지역사회에서 일어나는 사회 현상에 관여할 가능성이 여성에 비해 상대적으로 높다는 의미로 해석해 볼 수 있으며 이러한 결과가 본 연구에서 도 나타나고 있는 것으로 사료된다.

응원 팀에 따른 인식에서는 롯데 팬 집단의 지역사회 관여 인식이 가장 높게 나타났다. 시민의 참여활동 결정 은 보통 세 가지 의사결정을 통해 이루어진다. 첫째는 참 여활동을 할 것인가의 개인의 의사결정 여부, 둘째는 행 동의 방향, 셋째는 행동의 강도, 지속기간 및 극단성에 대 한 결정이다 (Kim, 2012). 반면, 시민의 적극적 참여가 저 조한 원인으로는 시민들의 태도나 선호, 필요한 자원의 부 족, 정치적 효능감의 문제 (Piven \& Cloward, 1988)가 있 으며 시민적 의무감 결여, 정치 정당과의 관계성 저하, 교 육적 자원 등을 제시하기도 한다(Rimmerman, 1997). 즉 시민들의 적극적 참여를 이끌어 내기 위해서는 지역사 회가 얼마나 역동적인가, 또는 효용 가능한 자원을 얼마 만큼 보유하고 있는지 여부가 지역시민들의 적극관여 유 도에 영향을 미치는 것이다. 본 연구 조사대상 지역 중 부 산광역시는 조사당시 여름철 행사가 막 끝난 무렵이었 으며, 동시에 부산사직야구장 재건축에 대한 논란이 일어 난 시점과 비슷한 시기였다. 우선, 부산은 바다라는 자연 환경을 활용한 축제를 통해 지역 시민들의 참여뿐만 아 니라 타지역 시민들까지도 지역행사에 적극적 참여를 유 도할 수 있었다. 또한, 당시 서병수 부산시장은 '사직구장 재건축 용역 검토'를 공식적으로 발표함으로써 부산지 역 롯데 팬들의 직간접적으로 의견을 표출하도록 함으 로써 지역사회의 의사결정에 시민들이 참여할 수 있는 환 경이 조성되었다. 이처럼 부산지역은 타지역에 비해 상대 적으로 지역 시민들의 적극 참여를 이끌어 낼 수 있는 자 원을 폭넓게 보유함으로써 시민들의 지역 관여를 유도하 였으며 이에 대한 시민들의 지역사회에 대한 적극적 관여 인식이 본 연구에서도 나타난 것으로 판단된다.

\section{일반적 특성에 따른 지역사회 인식 중 자긍심 요인 논의}

성별에 따른 인식은 남성 집단의 평균이 높게 나타났 다. 지역자긍심은 지역사회라는 일정한 공간 영역 내에 
서 구성원간의 상호작용을 통해 형성되는 자신의 긍정 적 심리상태로써 지역사회에 갖는 관심이라 할 수 있다 (Kim \& Lee, 2018; Wood, 2006). Deresiewicz(1997) 은 지역자긍심은 지역을 타인에게 자랑하고 싶고 타인 에게 소개하고 싶은 것이라고 하였다. 이는 다시 말해 내 가 속한 지역사회에 대해 아는 것이 많을수록, 즉 적극 참여하여 지역사회에 대한 인식과 지식의 폭이 넓을수록 지역자긍심이 높아질 확률이 높다는 의미이다. 아직까지 한국사회에서는 남성이 여성에 비해 지역사회 내 참여율 이 높다(Chae, 2016). 참여율이 높다는 의미는 그만큼 지 역사회 시정에 밝고 지역사회에 대한 지식이 많다는 의 미가 된다. 따라서 남성의 활발한 지역사회 내 활동과 관심이 지역사회의 자긍심을 높일 수 있는 요소를 더욱 잘 알게끔 하는 요인이 되는 것으로 생각된다.

응원팀에 따른 인식은 기아 팬 집단인 광주지역 팬들 의 지역자긍심이 가장 높게 나타난 것을 알 수 있다. 광주 지역은 2013년부터 강운태 광주시장을 필두로 '위대한 광주 자긍심' 심기를 지역모토로 삼고 있다. 이에 힘입어 무등산 국립공원 승격, 세계디자인비엔날레연맹 총회 유 치, 세계수영선수권대회 유치 등 지역사회에서는 쉽게 하 기 힘든 다양한 사회문화 행사를 연이어 유치하였다. 뿐 만 아니라 광주는 야구명문 광주일고의 지역 연고지이며 해당 학교 출신의 많은 스타선수(선동렬, 이종범, 서재응, 김병현 등)를 시민들은 지역사회의 큰 자부심으로 생각하 고 있다(Min, 2013). 따라서 광주지역은 지역사회에서 유 치가 힘든 굵직한 행사 유치와 타 지역에 비해 우수한 야 구명문 학교와 스타들을 보유하고 있는 것이 지역시민들 의 지역사회 자긍심을 높이는 원인 중 하나가 되고 있는 것으로 판단된다.

관람경력에 따른 인식은 8-15년 집단의 평균이 가장 높게 나타났다. 관람경력이 8-15년 미만, 15 년 이상 집단 의 평균이 높은 위치에 있는 것을 토대로 볼 때 어느 정 도의 야구관람 경력이 있는 집단일수록 지역사회에 대 한 자긍심도 높아지고 있는 것을 알 수 있다. 관람경력이 직접적으로 지역자긍심 향상에 영향을 미치는 핵심 요소 라고 해석하기에는 무리가 따른다. 그러나 야구관람 경 력이 약 8년 이상인 집단은 프로야구 경기 자체와 경기 가 열리는 경기장에 대한 애착도가 있는 집단이며 (Kim $\&$ Lee, 2018) 지역의 명물이자 명소로써 팀과 야구장에 대한 애착도가 지역자긍심과 연결되고 있는 것으로 사료 된다.

\section{일반적 특성에 따른 지역사회 인식 중 계층화 요인 논의}

학력에 따른 계층화 인식의 차이는 대졸집단의 평균 이 가장 높게 나타났다. 대졸집단은 사회적 지위 또는 소 득분위가 대졸이하 집단보다 높다. 이는 자본의 유무, 사 회적 자원의 유무, 지위의 높고 낮음에 따라 구분되는 계 층의 장점과 단점을 잘 알고 있는 집단일 가능성이 높다 (Han et al., 2004; Lee \& Kang, 2017). 또한, 본 연구에 서 사용된 계층화 관련 설문은 다른 사람에 비해 학력, 경 제수준, 문화생활 등이 더욱 나은 상황에 위치해 있다고 생각하느냐를 묻는 문항으로써 타인 보다 내가 더 높은 계층인가에 대한 인식을 확인할 수 있는 문항으로 구성되 어 있다. 결론적으로 대졸이상 집단은 그 이하 집단보다 지역사회 내에서 교육·경제·문화 수준이 더 높다고 생각 하고 있는 것으로 보이며, 객관적 지표가 될 수 있는 학력 이 높은 집단일수록 이러한 사고체계를 가지고 있을 가능 성이 높은 것으로 판단된다.

응원팀에 따른 인식의 차이는 롯데 팬 집단의 평균이 가장 높게 나타났다. 이는 곧 롯데가 연고지로 삼고 있는 부산·울산·경남 시민들의 계층인식이 타 지역에 비해 전 체적으로 높게 나타나고 있음을 짐작해 볼 수 있다. 서울 대학교 행정대학원 서베이조사연구센터는 2015년도에 '국 민인식조사'를 실시하였는데 그 조사 결과에서도 본 연구 결과와 유사한 결과가 나타났다. 상기 조사기관은 전국 성 인 남녀 5,940명을 대상으로 '자신의 사회 계층이 어디에 속하는가'에 대한 조사를 실시하였다(Hong, 2015). 그 결 과 울산, 부산, 충북 순으로 소득수준면에서 자신들이 상 위계층이라고 인식하는 사람들이 많은 것으로 나타났다. 본 연구에서의 계층화 인식이 타인에 비해 더 나은 계층 에 속하는지에 대한 인식을 물어봤다는 점에서 롯데 팬들 의 계층화 인식이 높은 평균을 나타내고 있는 것은 '국민 인식조사' 결과와 유사하다. 이같은 결과가 나타나게 된 원인은 울산 현대자동차 공장과 항만.부두의 역할이 크다 고 볼 수 있다. 우선, 현대자동차는 부산·울산.경남을 대표 하는 기업이며, 현대자동차의 공장과 기술교육원이 울산 에 있고, 자동차 출고 센터도 울산.양산·창원 세 곳에 흩 어져 있다. 따라서 현대자동차는 부산·울산·경남 전역에서 고용·생산·소비 등 경제 활동이 가장 활발한 기업이다. 비 록 롯데 그룹이 부산을 대표하는 기업인 것처럼 보이나 실질적으로 부산·울산 내에서 롯데그룹의 지지도는 $5 \%$ 
이내이며 현대그룹의 인지도가 $18 \%$ 이상을 기록하고 있었다(Noh, 2011). 또한, 부산은 신항만을 보유함으로 써 17 만명의 고용창출과 15 조의 생산유발 효과를 보고 있다. 따라서 부산·울산 팬들을 롯데 홈 팬으로 한정하고 있는 롯데자이언츠 팬들의 높은 계층화 인식에는 타 지 역에 비하여 고용과 생산유발 효과에 긍정적 영향을 미 칠 수 있는 자원을 다량 보유하고 있는 것이 계층화 인식 형성에 긍정적 영향을 미치고 있는 것으로 사료된다.

\section{일반적 특성에 따른 경기장 공간 인식 중 역사성 요인 논의}

응원팀에 따른 인식의 차이는 롯데 팬 집단의 평균이 가장 높게 나타났다. 롯데구단이 홈 구장으로 중인 사직 야구장은 LG, 두산, 한화구단이 사용하고 있는 잠실야구 장, 한화이글스파크보다 역사가 오래되지 않았다. 그러나 롯데자이언츠는 프로야구 출범 이후 단일 구단으로는 유 일하게 모기업이 변하지 않고 한 구장에서 계속해서 경기 를 치러오고 있다. 또한, 롯데자이언츠는 야구 도시로 불 리는 부산을 기반으로 하고 있으며 다른 어느 구단보다도 많은 팬을 보유하고 있다(Hwang, 2013). 결론적으로 롯 데 홈 팬들은 프로야구 출범 이후부터 현재까지 동일한 모기업이 같은 지역에서 활동하고 있는 '그들의' 구단을 부산지역의 문화자원으로 인식하고 있으며 경기가 열리 는 사직구장을 부산시민들은 프로야구의 역사가 쓰여지 는 공간으로 생각하고 있는 것으로 판단된다.

관람경력에 따른 인식은 8-15년 집단의 평균이 가장 높게 나타났다. 관람경력에 따른 인식은 앞서 설명한 관 람경력에 따른 '지역사회 자긍심' 인식 차이의 결과와 동 일하게 나타났다. 즉, 경기관람경력이 증가할수록 관람 행위 자체가 일상화가 되며, 이러한 라이프스타일이 이루 어지는 장소에 대한 기억·향수·역사성이 증가하게 된다 (Deaver, 2002; Perkins, 2015). 스포츠 스타디움은 파티 나(patina), 즉 '어떤 대상이 축적되어 가치를 더해주는 세월의 흔적'을 창출함으로써 지역사회가 얼마나 오랫동 안 그 대상물을 지켜왔는지, 그리고 집합적 기억을 지탱해 주는지를 판단하는 요소로써 스타디움의 역사성을 들 수 있다(Stillman et al., 2001). 따라서 경기장을 역사성 관 점으로 봤을 때 관람경력의 증가는 파티나(patina) 개념 의 생성과 연관성이 있으며, 경기장은 지역사회의 역사적 의미를 함축할 수 있는 공간이 될 수 있다.

\section{일반적 특성에 따른 경기장 공간 인식 중 고유성 요인 논의}

나이에서는 20 대 미만 집단의 평균이 가장 높게 나타 났다. 이는 야구경기장이 지역사회의 고유한 속성을 반영 한다는데 20 대 집단이 가장 긍정적 반응을 보인 것이다. 야구경기장은 새로운 건물이 들어서고 없어지는 요즘, 한 지역에서 오랜 기간 동안 자리 잡고 있는 건축물 중 하나 이다. 따라서 야구장에 대한 의미는 세대에 따라 차이가 날 수 있다 (Koppett, 1991). 현재 20대는 새로움을 뜻하 는 '뉴(new)'와 복고를 뜻하는 '레트로(retro)'를 합쳐 '뉴 트로(new-tro)' 시대에 살고 있다. 이는 소위 복고를 뜻하 는 말이다. "복고는 중장년층에게는 추억을 떠올리고 향 수를 느끼게 해주지만, 20 대 젊은 층에는 처음 접해 보는 신선하고 새로운 문화”라는 의미이다(Yoon, 2019). 요약 하면 뉴트로 문화의 특징은 공간과 같은 하드웨어만 옛 것일 뿐 서비스방식이나 컨텐츠인 소프트웨어는 최신의 것을 말한다. 프로야구 경기장도 이러한 '뉴트로' 문화의 일부가 되고 있는 것으로 사료된다. 현재 각 지역의 경기 장은 거대한 건축물로써 지역사회의 랜드마크로 과거부 터 자리 잡고 있다. 특히, 지역을 연고로 하는 프로야구와 경기가 이루어지는 야구장은 그 지역만의 특색이 고스란 히 묻어있는 공간이다(Stillman et al., 2001). 따라서 20 대들은 지역사회에서 오랫동안 자리 잡고 있는 경기장의 옛스러움과 그 안에서 일어나는 홈 팀의 경기, 지역 출신 선수 및 감독, 최신 응원가, 지역 특유의 응원문화 등을 경기장 내·외에서 느낄 수 있는 뉴트로 문화로 인식하고 있는 것으로 보이며, 이러한 장소를 제공해 주는 경기장 을 지역의 고유한 특색이 드러나는 공간으로 인식하고 있 는 것으로 사료된다.

응원팀에 따른 인식은 롯데의 평균이 가장 높게 나타 났다. 롯데의 경기장 고유성이 가장 높게 나타난 이유는 경기장 내 응원문화가 큰 비중을 차지하고 있는 것으로 보여진다. 부산 롯데 팬들의 경기장 응원문화는 전국적 으로 유명하다. 언론에서는 사직야구장을 거대한 '노래방' 이라고 표현하며 홈 지역인 부산을 야구도시 '구도(球都)' 라고 말하는 것이 대표적인 예다. 또한, '돌아와요 부산 항에', '부산갈매기'는 롯데자이언츠의 대표 응원가로써 경기를 진행하는 동안 팬들이 수시로 부르며, 신문지 응 원, 라이타 응원 등은 롯데자이언츠만의 대표 문화이다 (Park, 2011). 이처럼 롯데자이언츠의 홈 구장인 사직구 
장은 부산 시민들의 애향심을 높일 수 있는 공간이며 부 산 시민들의 '화끈한' 특성을 자유롭게 발현할 수 있는 장 소로 사용되고 있는 것으로 보여진다.

\section{일반적 특성에 따른 경기장 공간 인식 중 상징성 요인 논의}

나이에 따른 인식은 20 대 미만 집단의 평균이 가장 높 게 나타났다. 20 대들의 경기장 상징성이 가장 높게 나 타난 이유는 경기장을 역사적 가치와 의미성이 있는 건 축물로 생각하기 때문인 것으로 판단된다. 현재 많은 20 대들이 해외여행을 즐겨 가며 주로 쉬거나, 맛있는 것을 먹거나, 유명 관광명소를 즐겨 찾는다(Korea Tourism Organization, 2017). 소위 관광명소라고 하는 곳은 역사 적 의미를 가진 장소 또는 공간을 주로 의미하며 예로 옛 도시, 옛 건축물 (고궁, 성당 등)을 지칭한다. 경기장도 관 광명소의 대상이 될 수 있으며 (Gordon, 2013; Hinch \& Higham, 2005) 오래된 경기장이나 명소, 스포츠 역사 박물관 등을 찾아 가는 '노스텔지어 투어리즘(Nostalgia Tourism)' 이 이에 해당한다. 20대들이 옛 건축물을 보기 위해 해외에 나간다는 것은 그만큼 국내에는 역사적, 상 징적 건축물이 부족하다(Yoo, 2015)는 의미로 해석해 볼 수도 있다. 현재 국내 경기장도 유사한 맥락에 있는 것으로 판단된다. 현재 국내 많은 경기장이 비용상의 문 제로 철거되거나 이전 또는 리모델링되는 경우가 많다 (Kim \& Park, 2010). 그럼에도 불구하고 경기장은 해당 지역의 역사와 전통을 유지하며 한번 지어진 경기장은 쉽 게 철거하거나 옮길 수 없기 때문에 도시의 랜드마크로써 상징성을 가질 수 있다(Borer, 2008; Stillman et al., 2001). 따라서 본 조사에 참여한 20대 집단은 경기장을 경기관람 및 친목도모를 위한 장소로 인식함과 동시에 공 간에 대한 역사적 의미와 상징적 의미도 강하게 인식하고 있는 것으로 사료된다.

응원 팀에 따른 인식은 기아의 평균이 가장 높게 나타 났다. 다른 구장들과 달리 기아 구단이 홈 경기장으로 사 용하고 있는 구장은 2014년 2월에 경기장을 이전·재건 축하여 ‘광주챔피언스필드'라는 이름으로 새 단장 하였다. 또한, 이 구장은 2017년 KBO 리그 1군 9개 구장 중 가 장 아름답고 야구하기 좋은 구장으로 뽑혔다. 따라서 야 구에 있어서 역사와 전통을 자랑하는 광주지역에 최신 식 시설로 지어진 경기장을 광주 시민들은 자랑스러워하
고 있으며 자부심의 상징으로 인식하고 있는 것으로 판 단된다.

관람경력에 따른 인식은 8-15년 집단의 평균이 가장 높게 나타났다. 경기장 공간에 대한 상징적 인식에 있어 관람경력이 8-15년집단의 평균이 가장 높게 나타난 것 은 이전 결과 중 경기장 공간에 대한 역사성에서도 8-15 년 집단의 평균이 가장 높게 나타난 것과 일치한다. 이를 토대로 볼 때 관람경력 8-15년 미만 집단의 경우 경기장 공간에 대한 다양한 인식들이 강하게 형성되는 시기임을 짐작해 볼 수 있다. Kim \& Lee(2018)의 경기장 공간에 대한 팬의 사회적 인식연구에서도 이와 유사하게 관람경 력 8년 이상 집단의 경기장에 대한 정서적 애착이 가장 높게 나타났으며 Seol et al.(2009)의 연구에서도 프로 야구팬들의 관람 경력이 많을수록 경기장에 대한 애착도 가 높아진다는 결과가 본 연구결과를 뒷받침 해 주고 있 다. 그러나 관람경력을 일반변인으로 둔 다수의 선행연 구에서 15년 이상 집단에 대한 결과를 찾아보기가 힘들 었다. 반면, 본 연구에서 15 년 이상 집단의 비중은 161 명 으로 가장 크지만 경기장에 대한 상징적 의미가 가장 낮 게 나타난 것을 확인할 수 있다. 이는 관람경력이 15년 이상인 집단은 경기장에 대한 지역 내 상징성 보다는 향 후 만들어 갈 역사성에 더 큰 의미를 두기 때문인 것으 로 판단된다. 따라서 경기장 공간 인식형성에 있어 관람 경력 8-15년 미만이 역사성과 상징성 인식이 가장 높아 지는 시기인 반면 15 년 이상 집단은 상징성 인식에는 어 느 정도 관성이 생기고 역사성에 더 큰 가치를 두고 있는 것으로 해석해 볼 수 있다.

\section{홈 팬의 지역사회 인식이 따른 경기장 공간 인식 중 r역사성 인식」에 미치는 영향 논의}

소속감, 지역자긍 요인 인식이 높을수록 역사성 인식 이 높아지는 반면 계층화 인식은 높을수록 역사성 인식이 낮아지는 것을 알 수 있다. 경기장은 지역사회 내 오랜 건 축물 중 하나이다. 보통 새로운 경기장이 특정 지역에 지 어지면 보통 30년이 지난 후 이전·재건축 혹은 리모델링 논의가 이루어지는 경향이 있다(Kim et al., 2013). 이는 곧 그 지역에 30 년 이상 경기장 건축물이 자리잡고 있다 는 것이며, 해당 지역 주민들은 30년 이상 경기장과 함께 살아가야 한다는 의미가 된다. 많은 경기장 중 프로야구 경기장이 주는 의미는 특별하다(Eckberg \& Hill, 1979; 
Trujillo, 1992). 프로야구는 지역 연고 스포츠이기 때문 에 지역사회와 궤를 같이한다. 즉, 지역 시민들이 가질 수 있는 지역사회 인식에 프로야구 팀과 경기장에서의 경험 도 지역사회 인식 형성에 역할을 한다는 의미로 해석해 볼 수 있다. 자치단체 지역장들이 선거철에 프로야구경기 장 재건축 및 리모델링을 언급하는 이유도 이러한 사실과 관련이 없지 않다. 프로야구 경기장의 좌석은 홈 팬과 원 정 팬 좌석으로 구분된다. 많은 지역 시민들이 자발적으 로 한 공간속에 모이는 경우는 프로야구가 열리는 날이 거의 유일하다(Chapin, 2004; Hamilton \& Kahn, 1996; Richmond, 1995). 다시 말해 경기장 밖 지역사회 경험 인 식의 연장이 경기장 공간 안의 홈 좌석이라는 의미이다. 지역사회에 대한 인식을 형성하는 요인 중 일부가 지역에 소속감, 자긍심, 계층화 인식이라는 점을 생각해 볼 때 경 기장 안에서도 이러한 인식의 형성과 공유가 일어나고 있 는 것이다. 따라서 30 년 이상 지역사회에서 자리 잡고 있 는 경기장 공간은 지역사회의 삶, 역사와 궤를 함께 하며 특히, 지역사회에 대한 소속감과 적극관여 자긍심 인식이 긍정적일수록 경기장 공간의 역사성 인식도 긍정적으로 형성될 것으로 추론해 볼 수 있다. 반면, 계층화 인식은 낮을수록 경기장 역사성 인식이 높아지고 있다. 지역사회 내 계층화 인식은 지역사회 통합을 저해함과 동시에 분열 을 조장하며 사회에 부정적 영향을 미친다(Kim, 2017; Lee, 2018). 따라서 경기장 밖 계층화 인식과 같은 부정 적 인식이 경기장 내 지역시민들이 모여 있는 공간 속으 로 들어온다면 경기장 공간도 역시 부정적 인식이 누적되 는 공간으로 사용될 것이며 역사성 형성에도 방해요인이 될 것으로 사료된다.

\section{팬의 지역사회 인식이 따른 경기장 공간 인식 중 ‘고유성 인식,에 미치는 영향 논의}

소속감, 지역자긍심 요인 인식이 높을수록 야구경기장 공간의 고유성 인식이 높게 나타난다는 것을 알 수 있다. 고유성(固有性)은 그 문화가 지니는 '원형'을 뜻하고, 진 짜이며, 실제적이고 그 문화만이 가지는 독특성을 의미한 다(Kim, 2010). 사전적 의미는 '어떤 사물이나 겨레가 원 래부터 가지고 있는 성질'이라 하여 본질이나 개념을 의 미한다. 그러나 '고유'라는 말은 문자 그대로 본래부터 있 었다는 뜻은 아닌 다른 것과 같으면서 다른 것과 구별되 는, 다른 곳에서 다시 있을 수 없는 것을 '고유'라고 한다
(Tak, 2001). 따라서 고유성이란 그 대상이 지니는 '원형', '독특성', 또는 '다른 것과 구별되는 것', '다른 곳에서 다 시 있을 수 없는 것'을 고유성이라 정의할 수 있다. 팬들 은 지역사회에 대한 소속감, 자긍심이 높으면 높을수록 상징성을 가지는 경기장에 대한 고유성이 높아질 수 있 다. 최근 많은 경기장들이 그 지역만의 독특한 특성을 반 영하여 경기장을 짓거나 리모델링을 한다. 예를 들어 $\mathrm{SK}$ 와이번스의 문학구장은 가족 친화적 구장을 모토로 하여 바비큐존, 내·외야 패밀리존을 만들기도 하고 기아의 광 주챔피언스필드는 $\mathrm{K} 5, \mathrm{~K} 7 \mathrm{~K} 9$ 등 모기업 상품을 좌석 네 이밍으로 선정하기도 한다. 기아의 경우 경기장 공간의 '기업화는 모기업 마케팅의 일환 일 수 있다. 그러나 기아 자동차 공장이 광주에서 운영되어 지역사회 원동력이 된 다는 점을 고려해 본다면 지역 홈 팬들은 해당 경기장의 기업화를 광주 지역만의 고유성으로 인식하고 있는 것으 로 판단된다. 지역연고를 기본으로 하는 프로야구 구단들 은 지역사회에 사회·문화·경제적 기여를 제공함으로써 지역 시민들로 하여금 지역사회에 소속감과 자긍심을 높 이는 계기를 제공한다(Babiak \& Trendafilova, 2011; Park \& Park, 2014). 다시 말해, 지역자산의 일부인 구단 의 유무형적 지역사회 기여가 시민들의 지역사회에 대한 소속감, 자긍심을 고취시키며, 이러한 지역사회 소속감 과 자긍심이 경기장 고유성 인식의 강화로 연결되는 것으 로 생각해 볼 수 있다.

\section{홈 팬의 지역사회 인식이 따른 경기장 공간 인식 중 ‘상징성 인식」에 미치는 영향 논의}

소속감, 지역자긍심 요인 인식이 높을수록 야구경기 장 공간의 상징성 인식이 높게 나타난다는 것을 알 수 있 다. 경기장은 지역사회의 랜드마크로서 상징성을 가진다 (Meannig \& Schwartoff, 2011; Santo, 2005). 랜드마크 란 말 그대로 그 지역을 대표하는 마크를 의미한다. 일례 로 삼성동은 코엑스, 잠실은 롯데월드가 연상되는 것이 좋은 예시가 될 수 있겠다. 즉 지역의 랜드마크는 해당지 역을 대표하기 때문에 해당지역 주민들의 이용성을 높임 과 동시에 타지역, 더 나아가 전국민을 상대로 홍보가 되 는 효과가 있다. 또한, 지역사회의 랜드마크로 자리매김 하기 위해서는 지역시민들의 지지가 선행되어야 한다 (Moon, 2016). 따라서 지역사회의 랜드마크인 야구장 역 시 지역사회를 대표하는 상징성이 더욱 강화되기 위해서 
는 지역시민들의 지역사회에 대한 소속감과 자긍심이 높 아져야 경기장에 대한 상징성도 함께 높아질 것으로 예상 해 볼 수 있다.

\section{결론 및 제언}

본 연구는 프로야구 홈팬들을 대상으로 지역사회에 대한 인식과 경기장공간인식간의 관계를 살펴보는데 목 적이 있으며 결과를 바탕으로 다음과 같은 결론을 내릴 수 있다.

첫째, 일반적 특성에 따른 지역사회와 야구경기장 공 간 인식간의 차이 중 홈팬들이 인식하는 지역사회 소속감 인식은 응원팀에서 기아가 가장 높다. 적극관여 인식은 성별, 응원팀에서 남성, 롯데가 가장 높다. 자긍심 인식은 성별, 응원팀, 관람경력에서 남성, 기아, 8-15년 미만이 가장 높다. 계층화 인식은 학력, 응원팀에서 대졸, 롯데가 가장 높다. 경기장 공간 인식 중 역사성 인식은 응원팀, 관람경력에서 롯데, 8-15년 미만이 가장 높다. 고유성 인 식은 나이, 응원팀에서 20 대, 롯데가 가장 높다. 상징성 인식에서는 나이, 응원팀, 관람경력에서 20 대, 기아, 815 년 미만이 가장 높다.

둘째, 지역사회 인식이 야구경기장 공간 인식에 미치 는 영향 중 지역사회 인식이 경기장 공간 역사성 인식에 미치는 영향은 소속감, 지역자긍요인이 정 $(+)$ 적 인 영향 을, 계층화 요인은 부(-)적인 영향을 미친다. 홈팬들의 지역사회 인식이 경기장 공간 고유성 인식에 미치는 영 향은 소속감, 지역자긍 요인이 정 $(+)$ 적인 영향을 미친 다. 홈팬들의 지역사회 인식이 경기장 공간 상징성 인식 에 미치는 영향은 소속감, 지역자긍 요인이 정 $(+)$ 적인 영향을 미친다.

이를 종합적으로 분석해 보면 지역사회의 소속감, 지 역자긍요인이 경기장의 역사성·고유성·상징성 형성에 공 통적으로 유의미한 영향을 미친다. 다시 말해, 대중들은 지역사회 소속감과 지역사회 자긍요인을 가질수록 경기 장 공간 인식도 긍정적으로 형성되고 있는 것이다. 결국 지역사회는 시민들에게 소속감과 지역 자긍심을 느낄 수 있는 자원을 어떻게, 얼만큼 마련하느냐, 그리고 지역 시 민들은 지역사회 유무형의 자원이 그들에게 어떻게 인식 되느냐가 경기장 인식형성을 위해 중요한 것이다. 경기장 또한 지역사회의 자원 중 하나이다. 물리적 공간으로서
경기장은 지역사회 유형의 자원이자 특정 지역의 상징적 건축물로써 기능한다. 그러나 인지적 공간의 개념으로 접 근하면 경기장은 지역시민들이 삶에서 겪는 긍정적·부정 적 경험의 연장선에 있는 공간이며 지역사회 속에서 경험 하는 시민, 즉 팬들의 희노애락이 표출되는 공간으로서 기능한다. 단적인 예로 광주기아타이거즈는 과거 80년대 해태타이거즈 당시 82년 프로야구 출범때부터 99년까지 5 월 18 일에는 단 한번도 홈경기를 하지 못했다. 광주무 등야구장에 모인 광주시민들의 시위를 두려워한 군부 정 권이 광주 홈경기를 못하도록 막았기 때문이다. 원정경기 를 치러야 했던 해태타이거즈 선수들은 18년 동안 5월 18 일에 진행된 11 경기에서 8할이 넘는 승률을 기록하였 다. 물론 현재 광주챔피언스필드는 과거 광주무등야구 장과는 의미가 다르다. 그러나 통시적으로 볼 때 광주무 등야구장은 호남 지역 야구팬들의 정서가 담겨져 있던 역 사적 성지로써 현재까지도 회자 되고 있으며 광주챔피언 스필드 역시 무등야구장 옆에서 과거의 역사성과 고유성, 상징성을 유지한 채 새로운 지역사회의 역사를 써내려가 고 있다. 이처럼 팬들은 지역사회에서 어떠한 경험을 하 는지, 그를 통해 지역사회에 대한 인식이 어떻게 형성되 는지에 따라 경기장 공간 인식이 다양하게 형성되고 있 는 것이다.

본 연구 결론을 토대로 다음과 같은 제언을 할 수 있 다. 향후 연구에서는 본 연구와는 반대로 지역 홈팬들의 경기장에 대한 인식이 지역사회 인식에는 어떤 영향을 미 치는지에 관한 비교연구를 실시할 필요가 있다. 또한, 구 단 인식과 모기업 인식에 따라 경기장 공간인식이 어떻 게 달라질 수 있는지, 지역사회 인식이 어떻게 달라질 수 있는지를 확인할 수 있는 연구가 필요하며 이는 지역사회 자산으로써 구단과, 경기장이 지역사회에 긍정적 역할을 강화시킬 수 있는 방안을 모색할 때 도움이 될 것으로 사 료된다.

\section{참고문헌}

Babiak, K., \& Trendafilova, S. (2011). Corporate social responsibility and environmental responsibility: Motives and pressures to adopt green management practices. Corporate Social Responsibility and Environmental Management, 18(1), 11-24. 
Bale, J. (1991). Playing at home: British football and a sense of place. British football and social change: Getting into Europe, 130-144.

Borer, M. I. (2008). Faithful to Fenway: Believing in Boston, baseball, and America's most beloved ballpark. NYU Press.

Chae, S. H. (2016). Study on the effects of social capital on national pride. The Korean Association of Governance Studies, 26(1), 25-49.

Chapin, T. S. (2004). Sports facilities as urban redevelopment catalysts: Baltimore's Camden Yards and Cleveland's Gateway. Journal of the American Planning Association, 70(2), 193209.

Chea, S. H. (2003). Woman, worker, woman worker : Gender and class in feminist, ethnographies. The Women's Studies, 65, 83-116.

Cho, H. Y. (2010). Conscripted modernization. Humanitas.

Cho, J. H. (2005, April 15). Professional baseball lacks "symbol" and "history." Ohmynews, Retrieved from January 3, 2019, http://star.ohmynews.com.

Cho, M. H., \& Yang, B. S. (2004). A Study on the naturality measurement of cultural tourism festival. The Korean Academic Society of Culture \& Tourism, 6(1), 336-354.

Cho, S. S., Koh, E. H., \& Kim, S. H. (2012). Sport fans' meanings to sporting spaces. The Korean Journal of Physical Education, 51(2), 77-85.

Cho, T. Y. (2008). The effect of cultural tour experience on authenticity, Tourism Satisfaction, and Quality of Life. Unpublished Doctoral Dissertation. Dongguk University.

Chun, S., Gentry, J. W., \& McGinnis, L. P. (2005). Ritual aspects of sports consumption: how do sports fans become ritualized? ACR Asia-Pacific Advances.

Cohen, A. P. (Ed.). (1982). Belonging: Identity and social organisation in British Rural cultures (Vol. 11). Manchester University Press.

Deaver, P. F. (2002). Final season: Fathers, sons, and one last season in a classic American ballpark. Fourth Genre. Explorations in Nonfiction, 4(1), 263-265.

Deresiewicz, W. (1997). Community and cognition in "pride and prejudice." Elh, 64(2), 503-535.

Eckberg, D. L., \& Hill Jr., L. (1979). The paradigm concept and sociology: A critical review. American Sociological Review, 44, 925-937.

Eckstein, R., \& Delaney, K. (2002). New sports stadiums, community self-esteem, and community collective conscience. Journal of Sport and Social Issues, 26(3), 235-247.
Gordon, K. O. (2013). Emotion and memory in nostalgia sport tourism: Examining the attraction to postmodern ballparks through an interdisciplinary lens. Journal of Sport \& Tourism, 18(3), 217-239.

Gratton, C., \& Henry, I. (Eds.). (2002). Sport in the city: The role of sport in economic and social regeneration. Routledge.

Hamilton, B. W., \& Kahn, P. (1996). Baltimore's camden yards ballparks. Johns Hopkins University, Department of Economics.

Han, J. H., Ahn, B. C., Kim, Y. H., Jang, J. H., \& Ha, J. R. (2004). Structural analysis of inequality in Korean society and its correction policy. Basic Research Task, 1-151.

Han, S. B. (2017). Building baseball stadia for professional clubs: A critical analysis on public goods discourses. Korean Journal of Sociology of Sport, 30(4), 45-69.

Hillary, R. (1995). Small firms and the environment. Groundwork.

Hinch, T., \& Higham, J. (2005). Sport, tourism and authenticity. European Sport Management Quarterly, 5(3), 243-256.

Hong, B. S., Ah, Y. A., \& Woo, E. J. (2012). Development of a marriage migration women's community adaptation scale. Social Science Research Review Kyungsung University, 28(4), 21-49.

Hong, J. H. (2015, July 18). Nine of ten Koreans "I am lowmiddle class" class awareness of Daegu citizens hits lowest among metropolitan communities. JoongAng Ilbo, Retrieved from Janury 5, 2019, https://news.joins.com.

Hong, Y. P. (2012). Introduction of basement, 1904 is right. The Modern Bibliography, 5, 214-228.

Hwang, B. H. (2016, October 3). Professional baseball spectators exceed 8 million, economic effects nearing to 2 trillion won. Newsis, Retrieved from December 3, 2018, http://www.newsis. com.

Hwang, I. J., \& Jung, H. M. (2012). Measures for enhancing the sense of local community through urban events: A comparative study of four Korean cities. The Review of Korean Studies, $35(2), 101-128$.

Hwang, Y. J. (2013). Lotte giants baseball team and its political implications. The 21st Century Political Science Association, 23(1), 115-135.

Jung, J. W. \& Lee, J. H. (2017). Professional sports revitalization of catalyst for urban growth: Focused on stadium in Incheon original downtown. The Incheon Institute, 12, 289316.

Jung, J. W. (2017). Exploration of gender identity, decision-making in female labor market, and performance. Korean Womens 
Development Institute Research Report, 2017(9), 60-70.

Kang, S. J., Ahn, J. W., Kim, J. H. \& Lee, H. J. (2013). A study on efficient use of Jin-ju sports complex focusing on connected with community. Journal of the Architectural Institute of Korea Planning \& Design, 33(2), 277-289.

Karp, D. A., \& Yoels, W. C. (1990). Sport and urban life. Journal of Sport and Social Issues, 14(2), 77-102.

Kim, J. E. (2011). Cultural perspectives on the changing process of Incheon-based professional baseball teams in the local community history. Study of Humanities, 16, 119-152.

Kim, C. H., Park, S. J., Kim, J. W., Choi, J. H., \& Cho, Y. C. (2013). Comparison of the re-location of the ice rink for the ice-hockey at the 2018 Pyeongchang winter olympics. Journal of Sport and Leisure Studies, 52(1), 97-108.

Kim, C. S. (2015). Relation of social security network building, civil culture and community unity. Unpublished Master Dissertation, Seoul Venture University.

Kim, D. J., \& Lee, S. G. (2018). A study on the effects of local resident's social-cultural influence and environmental impact on festival satisfaction and local pride. Korea Academic Society of Tourism Management, 33(1), 253-273.

Kim, E. Y. (2017). A study on the social perception of professional baseball fans about the new stadium space managed by baseball clubs. Unpublished Doctoral Dissertation. Hanyang University.

Kim, E. Y., \& Lee, W. Y. (2018). A study on the social perception of fans for the space of the new professional baseball stadium - based on Samsung lions park and Kia champions field - . The Korean Society of Sports Science, 27(6), 159-178.

Kim, H. J. (1995). A study on the 'context' of urban architecture. Unpublished Master Dissertation, Suwon University.

Kim, H. J. (2012). Factors influencing participation by local citizens. Korean Public Administration Review, 46(2), 213240.

Kim, H. Y., \& Lee, Y. B. (2015). The effect of poetry cultural historic site's authenticity on perceived value and preference. Korea Tourism Research Association, 29(11), 129-143.

Kim, J. C., \& Jung, J. W. (2013). A study of publicity assessment for securing publicity in Seoul mega sports complex outdoor underused space. Korean Institute of Spatial Design, 26, 83-90.

Kim, K. S. (2018, April 2). Controversy over rebuilding Sajik baseball stadium. Hankyoreh, Retrieved from December 3, 2018, http://www.hani.co.kr.

Kim, M. G. (2017). Public recognition of social conflicts and social cohesion and its implications. Health and Welfare Policy Forum, 245, 37-49.

Kim, M. G., \& Park, K. D. (2010). Modern and contemporary Korean sports heartland. Korean Society for Sport Anthropology, 5(1), 47-69.

Kim, M. J. (2016). A study on the impact of city image on regional esteem and regional loyalty: Focused on landmark recognition factors. Unpublished Master Dissertation, Pusan National University.

Kim, E. K. (2010). The effect of local culture and local event congruence on the perception of visitors' experience and authenticity. The Journal of Korean Association of Modern Japanology, 28, 253-274.

Koppett, L. (1991). The new thinking fan's guide to baseball. Simon $\&$ Schuster.

Korea Tourism Organization (2017). Survey on current status of national trip in 2017. Ministry of Culture, Sports and Tourism.

Kwon, B. H., Jeon, J. A., \& Oh, Y. C. (2010). The effects on festival brand image, the esteem of residents and regional loyalty. Korea Hotel \& Resort Association, 9(2), 7-21.

Lamalfa, K. M. (2005). U.S. patent no. 6,920,709. Washington, DC: U.S. patent and trademark office.

Lee, C. A. (2018, October 1). Changwon city "pay NC utility as much as budget invested in building new baseball stadium." Gyeongnam Ilbo, Retrieved from December 3, 2018, $\mathrm{http}: / /$ www.idomin.com.

Lee, C. G. (2010). A study on the business crisis overcoming of the international stadium in local society. Crisisonomy, 6(2), 109-138.

Lee, H. J. (2018). An analysis on the change in the subjective socioeconomic status of the youth and its effect on perception toward justice. Korean Journal of Sociology, 52(3), 119-164.

Lee, H. Y., \& Kang, S. H. (2017). A study on the effect of company characteristics on the relationship between the job value and occupational adaptation of college graduates. Korean Employment and Career Association, 7(2), 125-149.

Lee, R. M., \& Robbins, S. B. (1995). Measuring belongingness: The social connectedness and the social assurance scales. Journal of Counseling Psychology, 42(2), 232.

Lopreato, J., \& Hazelrigg, L. E. (1972). Class, conflict, and mobility: Theories and studies of class structure. Chandler House Press.

Maennig, W., \& Schwarthoff, F. (2011). Stadiums and regional economic development: International experience and the 
plans of Durban, South Africa. Journal of Architectural and Planning Research, 1-16.

Min, C. K. (2013, March 18). Highest number of professional baseball players and coaches, why is Gwangju-il high school strong. Chosun Ilbo, Retrieved from December 2, 2018, http://news.chosun.com.

Moon, J. M. (2016). Landmark and the twentieth century urban planning - Landmark's symbolic transformations and its implications for urban planning -. Institute for the Humanities, 63, 5-34.

Moon, S. L. (2014). Suggestions to maximize post-utilization of sports stadiums after mega-sports event. The Journal of Sports and Entertainment Law, 17(4), 11-26.

Noh, J. S. (2011, May 22). Local representative company is "Hyundai motor." Sisa-Journal, Retrieved from December 2, 2018, http://www.sisapress.com.

Park, C. S. (2011, October 25). Lotte fans "cheers up with newspaper" launches urban brand in Busan. Yonhap News, Retrieved from January 2, 2019, https://www.yna.co.kr.

Park, J. H. \& Shin, K. J. (2014). The types of experts' consciousness for the conservation and utilization of modern architecture. Korea Society of Design Trend, 42, 307-318.

Park, J. W. (2012). Domed stadium, medicine or poison? An analysis of social discourse on the construction of a domed stadium produced in the media. The Korea Contents Society, 12(7), 378-393.

Park, K. D., \& Park, J. J. (2014). The effects of corporate social responsibility in professional baseball teams on team pride, loyalty, and fan expansion. Journal of Sport and Leisure Studies, 58(1), 269-282.

Park, S. Y., \& Chang, K. R. (2009). The relationship of locally affiliated professional sport teams community identity, residents' perceptions and support intentions - Case of Gangwon football club. Korean Society of Sport Management, 14(4), 67-78.

Perkins, C. (2015). Geography and the methodological ballpark: Putting place into sports history. The International Journal of the History of Sport, 32(15), 1759-1763.

Piven, F. F., \& Cloward, R. A. (1988). Why Americans don't vote. Pantheon.

Ramshaw, G., \& Gammon, S. (2010). On home ground? Twickenham stadium tours and the construction of sport heritage. Journal of Heritage Tourism, 5(2), 87-102.

Richmond, P. (1995). Ballpark: Camden yards and the building of an American dream. Simon and Schuster.
Rimmerman, C. A. (1997). The new citizenship - unconventional politics, activism, and service (Boulder, CO: Westview Press, 1998).

Sampson, R. J., \& Groves, W. B. (1989). Community structure and crime: Testing social-disorganization theory. American Journal of Sociology, 94(4), 774-802.

Santo, C. (2005). The economic impact of sports stadiums: Recasting the analysis in context. Journal of Urban Affairs, 27(2), 177-192.

Seo, S. K. (2017). The impact of awareness of landmark on local self-esteem and competitiveness. Unpublished Doctoral Dissertation. Dong-Eui University.

Seol, S. C., Song, M. S., \& Yoo, J. H. (2009). A study on the correlational influence of spectator motivation, team attachment and viewing satisfaction with regard to spectator intention to revisit pro baseball games. Korean Journal of Sport Management, 14(4), 95-116.

Son, S. Y. (2014). The effects of symbolic sculptures as city landmarks on regional competitive power. Unpublished Master Dissertation. Chung-Ang University.

Stillman, G. R. T. (2001). The postmodern ballpark as a leisure setting: Enchantment and simulated de-mcdonaldization. Leisure Sciences, 23(2), 99-113.

Tak, S. S. (2001). Identity of Korea. Chaeksesang.

Trujillo, N. (1992). Interpreting (the work and the talk of) baseball: Perspectives on ballpark culture. Western Journal of Communication (includes Communication Reports), 56(4), 350-371.

Wood, E. H. (2006). Measuring the social impacts of local authority events: A pilot study for a civic pride scale. International Journal of Nonprofit and Voluntary Sector Marketing, 11(3), 165-179.

Yang, S. H. (2014). Effects of income segregation in urban residential areason residents' sense of social cohesion. Unpublished Doctoral Dissertation, Seoul National University.

Yeom, D. S., Yoon, S. M. \& Seok, H. K. (2018). An application plan of the experience-centered leisure space using community resources. The Korea Sport Society, 16(1), 107-114.

Yoo, H. J. (2015). What makes cities sustain. Eulyoo.

Yoo, I. P., \& Park Y. B. (2006). A study on the participation conduct of local inhabitant about festival. Journal of Tourism Management Research, 26, 87-115.

Yoon, K. H. (2019, January 1). From "newtro" to "camelezon": What is core trend in 2019? JoongAng Ilbo, Retrieved from January 1, 2019, https://news.joins.com. 
Yoon, S. H. (2018, November 9). Changwon city reviews name of "new baseball stadium" from scratch. Ohmynews, Retrieved from January 2, 2019, http://www.ohmynews.com.

Yun, J. K., \& Han, K. S. (2005). The relationship between com- munity attachment of sports event participants and community formation. Journal of Sport and Leisure Studies, 23, 605-616.

\title{
프로야구 홈 팬의 지역사회 인식이 경기장 공간 인식에 미치는 영향 연구
}

\author{
이완영(서울대학교 스포츠과학연구소), 권순용(서울대학교)
}

[목적〕 본 연구는 프로야구 홈팬을 대상으로 지역사회 인식이 경기장 공간인식에 미치는 영향을 살펴보는 데 목적이 있다. (방법) 대상은 프로야구 두산, LG, SK, 롯데, 한화, 기아 팬 100 명씩 총 600 명을 대상으로 조사를 실시하였으며 이중 총 510 부를 최종 분석 자료로 사용하였다. 수집된 자료는 SPSS 21.0 프로그램을 이용하여 전산처리 하였으며, 참여집단의 일반적 특성에 따른 인식 차이를 알아보기 위해 독립표본의 t-test 와 일원변량분석 (one-way ANOVA)을 실시하였고, 가설검증을 위해 상관분석(correlations analysis), 다 중회귀분석 (multiple regression analysis)을 실시하였다. 〔결과〕 홈 팬들이 인식하는 지역사회 인식 중 소 속감 인식에서는 응원팀에서 유의한 차이가 있었으며, 적극관여 인식에서는 성별, 응원팀에서 유의한 차이가 나타났다. 자긍심 인식에서는 성별, 응원팀, 관람경력에서 유의한 차이가 있었으며, 계층화 인식에서는 학력, 응원팀에서 유의한 차이가 나타났다. 경기장 공간 인식 중 역사성 인식에서는 응원팀, 관람경력에서 유의한 차 이가 나타났다. 고유성 인식에서는 나이, 응원팀에서 유의한 차이가 나타났으며, 상징성 인식에서는 나이, 응 원팀, 관람경력에서 유의한 차이가 나타났다. 홈팬들의 지역사회인식이 경기장 공간 인식 중 역사성 인식에 미 치는 영향은 소속감, 자긍심 요인이 정 $(+)$ 적인 영향을, 계층화 인식은 부(-)적인 영향을 미쳤고, 고유성 인식 과 상징성 인식에 미치는 영향은 소속감, 자긍심 요인이 정 $(+)$ 적인 영향을 미치는 것으로 나타났다. (결론) 본 연구 결과 지역사회와 프로야구 경기장은 밀접한 관계를 맺고 있으며 경기장에 대한 긍정적 인식 형성을 위해서는 지역사회에 대한 소속감과 자긍심을 공통적으로 높일 필요가 있다. 또한, 지역사회인식에 따라 경기 장 인식이 달라지는 것을 볼 때 소속 구단 인식, 모기업 인식 역시도 지역사회 인식과 밀접한 연관성이 있을 수 있으므로 유추할 수 있으며 이에 대한 향후 연구가 진행될 필요가 있다고 생각된다.

주요어: 프로야구, 홈팬, 지역사회, 경기장 공간 